\title{
Market microstructure, banks' behaviour and interbank spreads: evidence after the crisis
}

\author{
Burcu Kapar ${ }^{1}$, Giulia Iori², Giampaolo Gabbi ${ }^{3,4 *}$, Guido Germano ${ }^{5,6}$ \\ 1. American University in Dubai \\ 2. City, University of London \\ 3. University of Siena \\ 4. SDA Bocconi School of Management, Milan \\ 5. University College London \\ 6. London School of Economics and Political Science
}

22 March 2019

\begin{abstract}
We present a study of the European electronic interbank market of overnight lending (eMID) before and after the beginning of the financial crisis. The main goal of the paper is to explain the structural changes of lending/borrowing features due to the liquidity turmoil. Unlike previous contributions that focused on banks' dependent and macro information as explanatory variables, we address the role of banks' behaviour and market microstructure as determinants of the credit spreads. We show that all banks experienced significant variations in their liquidity costs due to the sensitivity of interbank rates to the timing and side of trades. We argue that, while larger banks did experience better funding conditions after the crisis, this was not just a consequence of the "too big to fail" perception of the market. Larger banks have been able to play more strategically when managing their liquidity by taking advantage of the changing market microstructure.
\end{abstract}

Keywords: Interbank lending, market microstructure, subprime crisis, liquidity management.

${ }^{*}$ Corresponding address: SDA Bocconi School of Management, Via Bocconi 8, 20136 Milano, Italy. E-mail: giampaolo.gabbi@sdabocconi.it 


\section{Introduction}

Interbank markets play a key role in the liquidity management of banks and in the transmission of monetary policy. Well-functioning interbank markets effectively channel liquidity from financial intermediaries with a surplus of funds to those in need, allowing for more efficient financial intermediation. Variations in interbank rates are transmitted to the entire term structure, affecting borrowing conditions for households and firms. Interbank rates provide benchmarks (e.g. the Libor, Euribor and Eonia) for the pricing of fixed-income securities and derivative contracts such as shortterm interest rate futures and interest rate swaps, used by banks to hedge their short-term interest rate risks. Thus, policymakers have an interest in a financial system with an efficient interbank market, that is, one in which the central bank can achieve its desired rate of interest and one that allows institutions to trade liquidity minimizing transaction costs and information asymmetries.

Before the crisis, interbank markets were among the most liquid in the financial sector and the literature has historically devoted a relatively low consideration to the interbank market due to the short-term nature of the exchanged deposits. Banks used to accept non-collateralised loans because counterparties were considered safe and sound enough and liquidity risk was perceived as marginal due to the central bank role as lender of last resort. However, during the 2007-2008 financial crisis, liquidity in the interbank market has considerably dried up, even at short maturities. Also an increasing dispersion in the credit conditions of different banks has emerged. These events have triggered a new interest in interbank markets. The dramatic change of volumes and the drop in the number of active banks after the subprime crisis can be hardly explained as a real reduction of liquidity need by banks. A number of papers in the literature have explained this "market freeze" with two hypotheses: liquidity hoarding versus credit monitoring (Heider et al. 2015, Acharya et al. 2013, Gale and Yorulmazer 2011). On the demand side, a possible explanation for the crunch suggested by Cassola et al. (2010) was adverse selection: banks prefer not to reveal their needs for liquidity, which could lead to credit rationing, and switch from a highly transparent electronic market to more opaque over-the-counter markets.

On the empirical side, a number of papers investigated the microstructure properties of the interbank market before the crisis. The US Federal Funds market was studied by Hamilton (1996), Furfine (2000), Furfine (2001) and Furfine (2002). Beaupain and Durré (2008) presented a comprehensive analysis of the dynamics of the Euro overnight money market using data until April 2007. They uncovered regular seasonal patterns of market activity and liquidity, as well as patterns determined by the Eurosystem operational framework. Iori et al. (2008) studied the evolution of the network topology of the European interbank electronic market (e-MID) within maintenance periods in the years 1999-2002 by applying methods of statistical mechanics. They showed that a large number of small/medium size banks tend to be liquidity providers for a small number of large banks; strategic behaviour, in terms of preferential and speculative lending, tends to be rather limited in e-MID. Baglioni and Monticini (2008) showed the presence of an intraday term structure of interest rates in a way that the overnight rate displays a clear downward pattern throughout the trading session, with banks borrowing at a premium early in the morning and at a discount at the end of the day. This finding for 2003-2004 was confirmed over the longer period 1999-2009 by Iori et al. (2015c) among several other empirical features of the e-MID they analysed for those 11 years.

An increasing number of studies has analysed how the financial crisis has affected the credit conditions of banks in the interbank market. Angelini et al. (2011) analysed the spreads between uncollateralised e-MID rates and collateralised repo rates on maturities from one week to 12 months. They observed that the mean spread increases and the distribution becomes more disperse during the crisis. The question they address is what share of the soaring spread is due to an increased bank-specific default risk and what to a generalised surge in risk aversion measured from the equity 
market. They find that before the crisis bank size is the only important borrower characteristic to determine spreads, and large banks get better rates. During the crisis the effect of borrower creditworthiness, measured by rating and capitalization, becomes significant, with larger banks still experiencing better borrowing conditions both before and after the Lehman collapse, but still small. The main determinant of the increasing spreads (two thirds of the effect) appears to be the overall increase in risk aversion. A similar effect of size on spread is found by Gabrieli (2012), who focuses on the overnight determinant of credit spreads, defined as the difference between the volume-weighted average daily interbank rate and the ECB policy rate. Berardi and Tedeschi (2017) studied how banks' strategies based on achieving a low interest rate and a high supply of liquidity influence the banks' performance and the network topology of the interbank market. Tedeschi et al. (2018) explored banks' reaction to financial shocks and how banks' strategies influence financial cycles. Schwarz (2018) estimated the credit risk measure through the default horizon mismatch of credit default swaps (CDS) with interbank spreads.

The above studies have focused on the role of borrower- and lender-specific features as well as market-wide effects to explain the rise in the spreads during the crisis. In this paper we provide new evidence that banks' strategic behaviour also played a role in determining the cross-sectional variations in lending and borrowing spreads. Our analysis shows that the crisis was a turning point in banks behaviour: while on average some banks managed the liquidity needs better or worse than others, they all experienced a large variability of their rates over time. Such variability is not easy to explain only in terms of bank-specific characteristics or idiosyncratic risks. After the turmoil, the interbank market microstructure became particularly relevant. We find that the time and the side of a trade significantly affect the funding rate: the higher the volume traded by a bank in the morning, the higher the spreads (that is, borrowing conditions deteriorate in the morning for borrowers and improve for lenders), and the higher the volume traded as quoters, the better the rates obtained by lenders and borrowers.

Our data source is the e-MID platform used by European banks to exchange uncollateralized interbank funds. We focus on the overnight segment of the market, which is the most liquid and represents about $90 \%$ of all interbank transactions. According to the European Central Bank, the e-MID accounted for $17 \%$ of total turnover in unsecured money market in the Euro Area before the crisis. Each bank in the dataset is identified by a unique code, its size class and nationality, so one can follow a bank's activity over time. However, not knowing the real identity of the banks, one cannot match individual interbank transactions with bank characteristics extrapolated from balance sheet and credit rating data ${ }^{1}$ Nonetheless, as shown by Angelini et al. (2011), bank characteristics, with the exception of size, only played a minor role in explaining cross-sectional variations in lending and borrowing spreads. This was partly because bank-specific creditworthiness, captured by variables such as credit ratings, capital ratios, or profitability remained roughly unchanged during the precrisis and crisis periods or improved slightly. Neither borrower and lender liquidity nor their shortage of capital correlated with spreads in the study of Angelini et al. (2011). This suggests that banks were unwilling to engage in peer monitoring efforts before and during the crisis. The effect of sizes, while significant, in itself is unlikely to reflect positively on the credit-worthiness of large banks that were more exposed to the crisis because of their complexity and international interconnection. Angelini et al. (2011) and Gabrieli (2012) argue that their results rather suggest the existence of a too-big-to-fail guarantee implicitly granted by the market to the banks with the highest volumes of business. In fact, the price benefit enjoyed by relatively bigger banks becomes much stronger after September 2008, i.e. when European governments were forced to make explicit the promise that

\footnotetext{
${ }^{1}$ While our main cross-sectional regression results do not incorporate banks' specific characteristics other than size and nationality, we perform an additional robustness check using a panel data model with time and bank fixed effects that can capture bank characteristics such as credit and liquidity risk.
} 
no other systemically important financial institution would be allowed to fail. Instead we argue that, while larger banks did experience better funding condition during the crisis, this was not just a consequence of the "too big to fail" perception of the market; rather we show that larger banks took advantage of the changing market microstructure.

The rest of this paper is organised as follows. Section 2 describes the properties of the e-MID market and analyses the dataset. Section 3 introduces the explanatory variables of the regression models. Section 4 explains the econometric methodology followed in this study and reports the empirical findings. Section 5 concludes.

\section{2 e-MID market and data}

This section is divided into two parts: the first introduces the characteristics of the e-MID interbank market; the second explains the dataset of interbank rates used for our empirical analysis.

\subsection{The e-MID market}

Interbank markets can be organised in different ways: physically on trading floors, by telephone calls, or on electronic platforms. In Europe, interbank trades are executed in all these ways. The only electronic market for interbank deposits in the Euro area and the USA is the e-MID (Mercato Interbancario elettronico dei Depositi) that was established in Italy in 1990. Under the supervision of the Bank of Italy, credit institutions and investment companies can participate in this market if their total net asset size is respectively at least 10 million US Dollars and 300 million Euros (or their equivalents in another currency). Interbank deposit maturities range from overnight to one year, with overnight contracts representing about $90 \%$ of the total volume. An overnight trade is defined as a transfer of funds on the day of the trade with return at 9am of the subsequent business day. Trading starts at $8 \mathrm{am}$ and ends at $6 \mathrm{pm}$. The large majority of volumes are traded in the Euro section of the market and, more specifically, on the overnight contracts. Before the financial crisis the platform had 246 members from 29 EU countries and the US, of which 30 were central banks acting as market observers to monitor the interbank deposit size and rates. After the Lehman failure, the number of countries with banks actively participating in the e-MID market was down to 16: Austria, Belgium, Denmark, France, Germany, Greece, Ireland, Italy, Luxembourg, Netherlands, Norway, Poland, Portugal, Spain, Switzerland and United Kingdom. In January 2014 the e-MID recorded 127 banks from 28 countries trading liquidity (92 Italian banks and 35 foreign banks) and 29 Central Banks as observers. The e-MID company itself is participated by 31 banks.

The number of transactions and the trading volume increased systematically until the beginning of the financial crisis, with an average of 450 transactions each day and an exposure for each transaction of about 5.5 million Euros. According to Baglioni and Monticini (2008), this evolution is due to the trend toward real-time settlement for payments, securities and foreign exchange transactions that took place in recent years. This trend has increased the value of intraday liquidity. As shown by Iazzetta and Manna (2009), interbank deposits as a percentage of total assets of the banking system doubled from $8 \%$ in 1993 to approximately $16 \%$ in 2007 . From the end of 2006 until mid-2008 the share of transactions executed via e-MID in the unsecured Euro money market has remained roughly unchanged at $17 \%$. After the crisis, the market share of the e-MID decreased to $10 \%$ (ECB Report 2011).

The main difference with respect to security markets is that market participants can choose their counterparties. An operator willing to trade can pick a quote and manifest his wish to close the trade. Trades are public in terms of maturity, rate, volume, and time. While the identity of 
the quoting bank is normally public too (the quoter may choose to post a trade anonymously, but this option is rarely used), the identity of the aggressor, that is the party that initiates the deal accepting the proposed transaction, can only be disclosed by a quoter during the negotiation phase. A quoter, i.e. a bank that is willing to lend capital and proposes a transaction, has the option to reject an aggression, and similarly an aggressor has the additional option of not closing a trade after knowing the counterparty, if this was not public. An aggressor can also subordinate his wish of closing a trade to specific requests, such as a larger or smaller volume or a different rate. The e-MID thus provides a transparent platform where all parties can monitor in real time the evolution of traded rates, while benchmarks like the Libor and Euribor, as seen in the 2012 Libor fixing scandal, can be easily manipulated. For more details on the order-driven market mechanism of the e-MID, see Iori et al. (2015c).

\subsection{Data}

The dataset used for this study consists of all transactions recorded in the platform between 15 June 2006 and 7 December 2009. The period after 2009 was characterised by the Greek crisis and the consequent contagion to the sovereign debt of other European countries; transactions on the interbank market were therefore affected more by the sustainability component of the public debt than by banking characteristics. For each transaction the bank size measured by total assets is provided in five categories: major banks ("MA"; total assets higher than 60 billion Euro), large banks ("LA"; from 26 to 60 billion Euro), medium banks ("ME"; from 9 to 26 million Euro), small banks ("SM"; from 1.3 to 9 million Euro) and minor banks ("MI"; less than 1.3 million Euro). The size classification was stable over time.

The database does not provide information on the state of the book, its dynamics and how the banks use this information when acting on the market. A dataset similar to ours was the object of a number of past studies (Angelini et al. 2011, Baglioni and Monticini 2008, Baglioni and Monticini 2013, Beaupain and Durré 2008, Brunetti et al. 2015, Finger et al. 2012, Galbiati et al. 2013, Iori et al. 2006, Iori et al. 2008, Iori et al. 2015a, Iori et al. 2015b, Iori et al. 2015c), while Brousseau and Manzanares (2005) performed a study using the full book information.

It is known that the trading activity of borrowers/lenders is affected by the reserve maintenance period announced by the ECB rather than by calendar month effects. This is so because banks need to comply with regulatory requirements on the average amount of liquidity held over such periods. Empirically, for the Eonia rates, Gaspar et al. (2008) report an increase in market activity towards the last days of the reserve maintenance period described by a remarkable increment in the number of transactions and the underlying volatility of interest. In order to reduce the noise due to extreme movements on daily funding spreads around the end of the reserve maintenance periods, we consider average monthly spreads computed over the entire reserve maintenance periods rather than daily observations. In our dataset, we have 42 monthly periods determined by reserve maintenance periods.

We also control the occurrence of structural breaks in the distributional relationship between funding rates and dependant variables by dividing our time period into three non-overlapping subperiods. Table 1 presents information about the subperiods considered in the study. Period 1, the pre-crisis, covers the period June 2006 to June 2007. Period 2, the subprime crisis, goes from the first outburst of the crisis until the Lehman Brothers default. We chose mid June 2007 as the flare-up of the crisis because at this date Bear Stearns \& Co informed investors in two of its CDO hedge funds that it was halting redemptions. This event was followed in mid July by Moody's downgrading of 131 ABS emissions backed by subprime residential mortgages; on July 30 by Germany's IKB reporting substantial losses and revealing that its main shareholder, KfW, had assumed 
its financial obligations; on August 9 by French investment bank BNP Paribas suspending three investment funds that invested in subprime mortgage debt, and on August 10 by central banks coordinate efforts to increase liquidity for the first time since September 11, 2001. Period 3, the post-crisis, represents the dates after the default of Lehman Brothers and most of the central bank interventions to sustain the liquidity need of the banking systems; it also includes the Northern Rock run occurred in mid September 2007 and the Bear Sterns default in mid March 2008.

Table 1: Definition of the studied sub-periods and number of reserve maintenance periods within each of them.

\begin{tabular}{llr}
\hline \hline Period & Dates & Reserve Maintenance Periods \\
\hline 1. Pre-crisis & 15 June 2006-12 June 2007 & 12 \\
2. Subprime crisis & 13 June 2007 - 7 October 2008 & 16 \\
3. Post-crisis & 8 October 2008-7 December 2009 & 14 \\
\hline \hline
\end{tabular}

Our empirical analysis focuses on funding spreads rather than funding rates, which could be affected by macroeconomic rather than risk factors. We analyse daily spreads and daily volatility as descriptive statistics to increase our understanding about the structure of the spreads during the time period considered and we focus on monthly spreads to run the regression models. The volume-weighted average daily credit spread $c_{j, d}$ for bank $j$ in day $d$ is defined as

$$
c_{j, d}=\frac{1}{V_{j, d}} \sum_{i=1}^{N_{j, d}} V_{i, j, d}\left(r_{i, j, d}-r_{d}\right) \text {, }
$$

where $V_{i, j, d}$ and $r_{i, j, d}$ are the volume and rate of transaction $i$ of bank $j$ in day $d, N_{j, d}$ is the number of transactions of bank $j$ in day $d$ and $V_{j, d}=\sum_{i=1}^{N_{j, d}} V_{i, j, d}$ is the total volume traded by bank $j$ in day $d ; r_{d}$ is the volume-weighted average rate of day $d$,

$$
r_{d}=\frac{1}{V_{d}} \sum_{j=1}^{N_{d}} \sum_{i=1}^{N_{j, d}} V_{i, j, d} r_{i, j, d},
$$

where $V_{d}=\sum_{j=1}^{N_{d}} V_{j, d}$ is the total trading volume of all $N_{d}$ banks active in day $d$. If in a given day $d$ a bank participates in both borrowing (buy) and lending (sell) transactions, two separate credit spread coefficients $c_{j, d}^{\mathrm{b}}$ and $c_{j, d}^{\mathrm{s}}$ can be defined. The credit spreads provide a measure of the ability of a bank to borrow or lend at competitive rates relatively to the mean rate observed in that day in the same market. Thus the spread does not depend on specific features of the interbank market with respect to other markets, such as when the spread in the uncollateralised market is defined by using a collateralised market as reference. Figure 1 shows the quantile plots of the cross-sectional daily borrowing and lending spreads. The figure clearly indicates that while, before the crisis, banks were experiencing similar credit conditions with respect to each other, during the crisis much more variation was observed among borrowers and lenders, with a peak in correspondence of the Lehman default. In fact the cross-sectional mean spreads became negative after the default of Lehman Brothers, indicating that several banks were experiencing better than average borrowing conditions (and worse than average lending conditions), but for a few banks in the tails trading happened on much worse terms. As mentioned before, there has been a considerable effort in the literature to explain this variation, and size has been identified as the main bank-specific factor to drive banks' spreads (Angelini et al. 2011, Gabrieli 2012). 

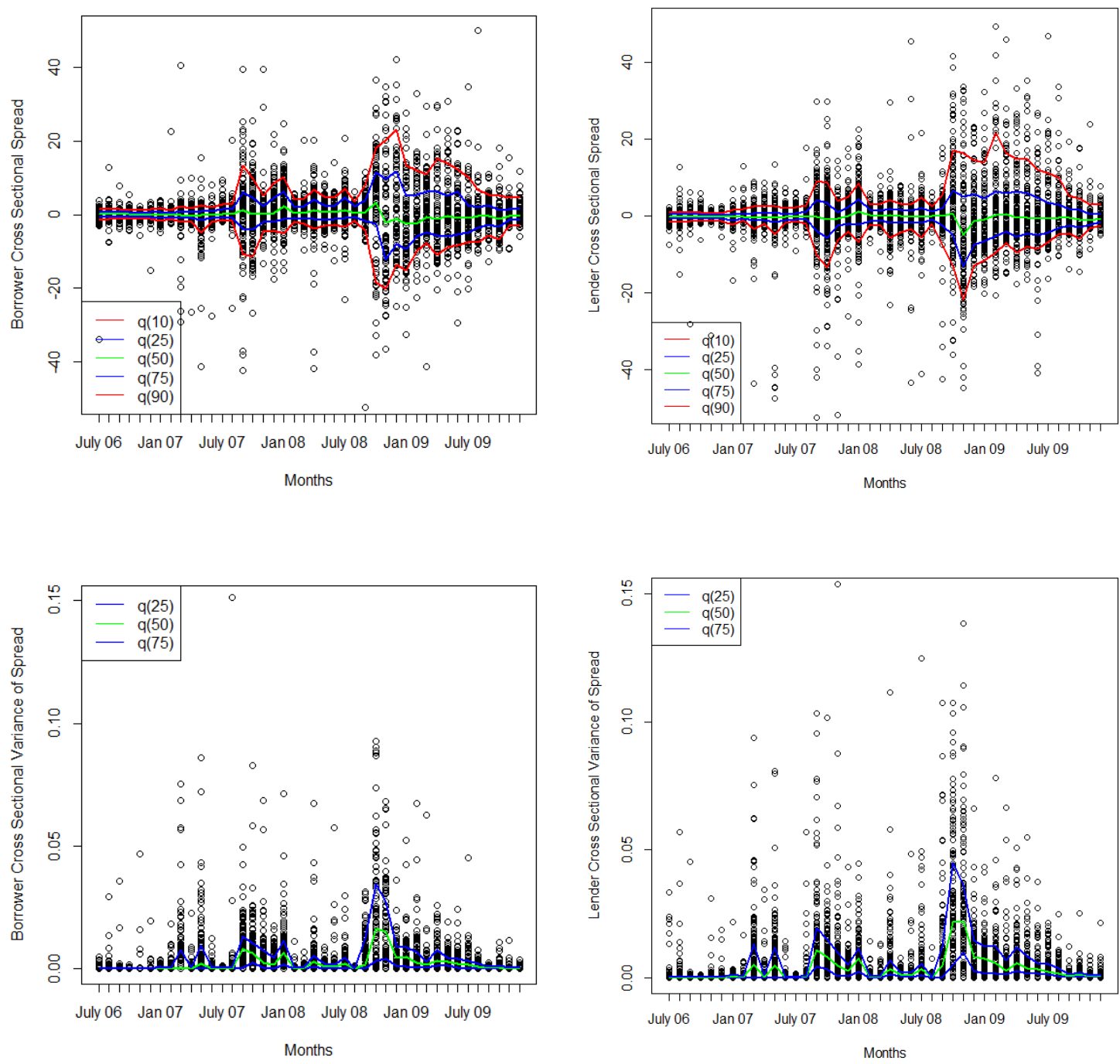

Figure 1: Cross-sectional spreads (top) and their variance (bottom) for borrowers (left) and lenders (right). 
Nonetheless, during the financial turmoil all banks have experienced a high variability in their borrowing and lending rates. Indeed the first contribution of our analysis is to show that not only the volatility of the average e-MID rate increased during the crisis, but also the borrowing and lending spreads of individual banks experienced a large variability too. To show this empirically, we calculate the volume-weighted variance of each bank

$$
\operatorname{Var}\left(c_{j, m}\right)=\frac{1}{V_{j, m}} \sum_{d=1}^{N_{j, m}} \sum_{i=1}^{N_{j, d}} V_{i, j, d}\left(r_{i, j, d}-r_{d}\right)^{2}-\left[\frac{1}{V_{j, m}} \sum_{d=1}^{N_{j, m}} \sum_{i=1}^{N_{j, d}} V_{i, j, d}\left(r_{i, j, d}-r_{d}\right)\right]^{2},
$$

where $V_{j, m}=\sum_{d=1}^{N_{j, m}} \sum_{i=1}^{N_{j, d}} V_{i, j, d}$ is the volume and $N_{j, m}$ is the number of transactions of bank $j$ in the reserve maintenance period $m$ of $N_{m}$ days. Figure 1 shows the quantile plot of the cross-sectional spread of individual banks and their variance separately for borrowing and lending transactions. These quantities considerably increased during the crisis, in particular after the Lehman default. Notably, while the spreads themselves do not show significant changes ahead of the summer 2007, the cross-sectional variance presents a significant peak in the early months of 2007, providing in this way the first early warning signal of the forthcoming crisis. Figure 2 shows the box plots of spreads for the different groups in the three periods. It appears that the major banks obtained the lowest borrowing spreads and the large banks the highest lending spreads (in Period 1 and Period 2) on average. Nonetheless these two groups experienced a variability comparable, if not larger, to that of the other groups.
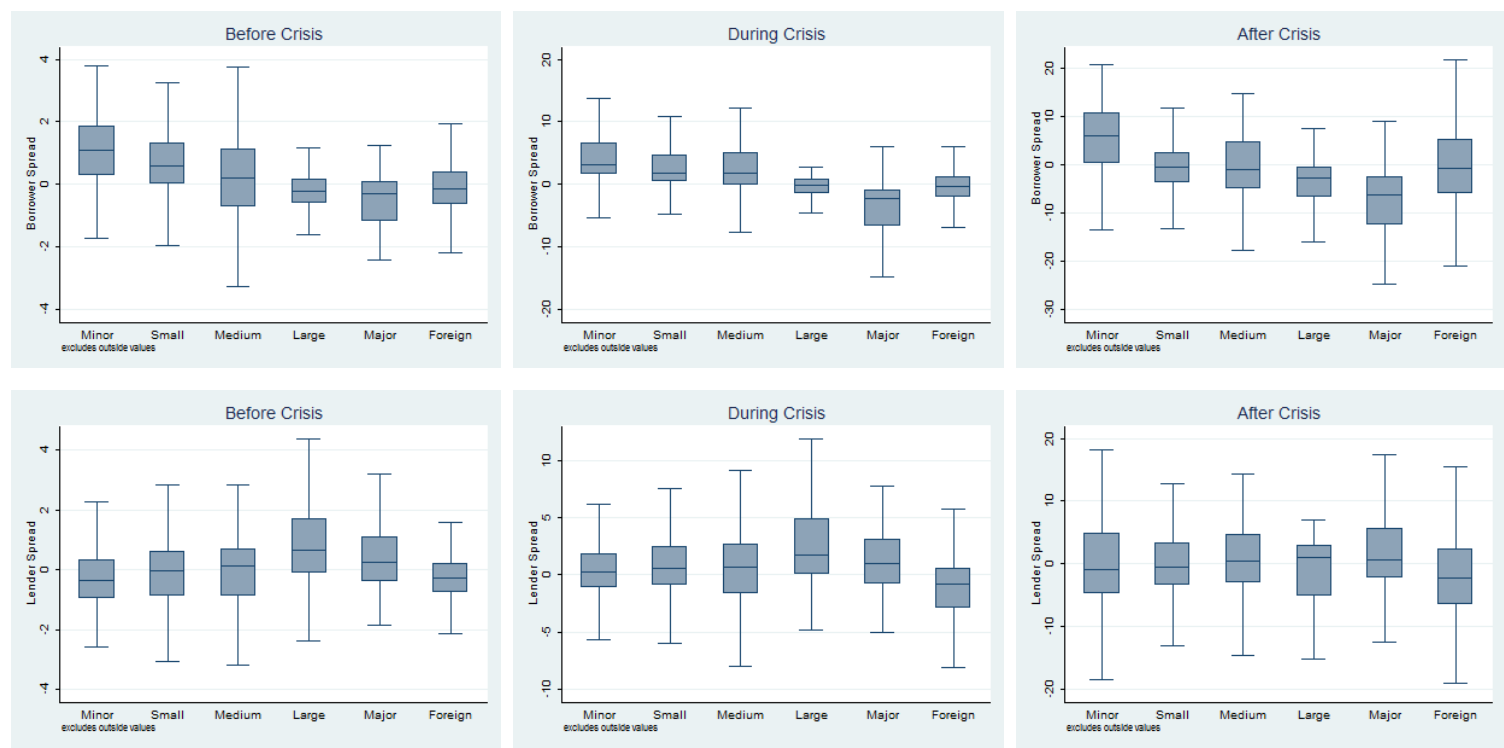

Figure 2: Borrowers (top) and lenders (bottom) spread for different groups of banks in Period 1 (pre-crisis, left), Period 2 (subprime crisis, middle), Period 3 (post-crisis, right).

Moreover, banks' good and bad performances were not consistent over time. As a measure of consistency of bank performance we measure the autocorrelation of lending and borrowing credit spreads in trading time units (banks differ substantially in term of size and frequency of trades, with some banks settling only a few trades in a year and others trading several times a day). We estimate the cut-off lag as the first time lag at which the autocorrelation becomes statistically not significant (at significance level 5\%). The meaning of this measure is to identify the continuity of 

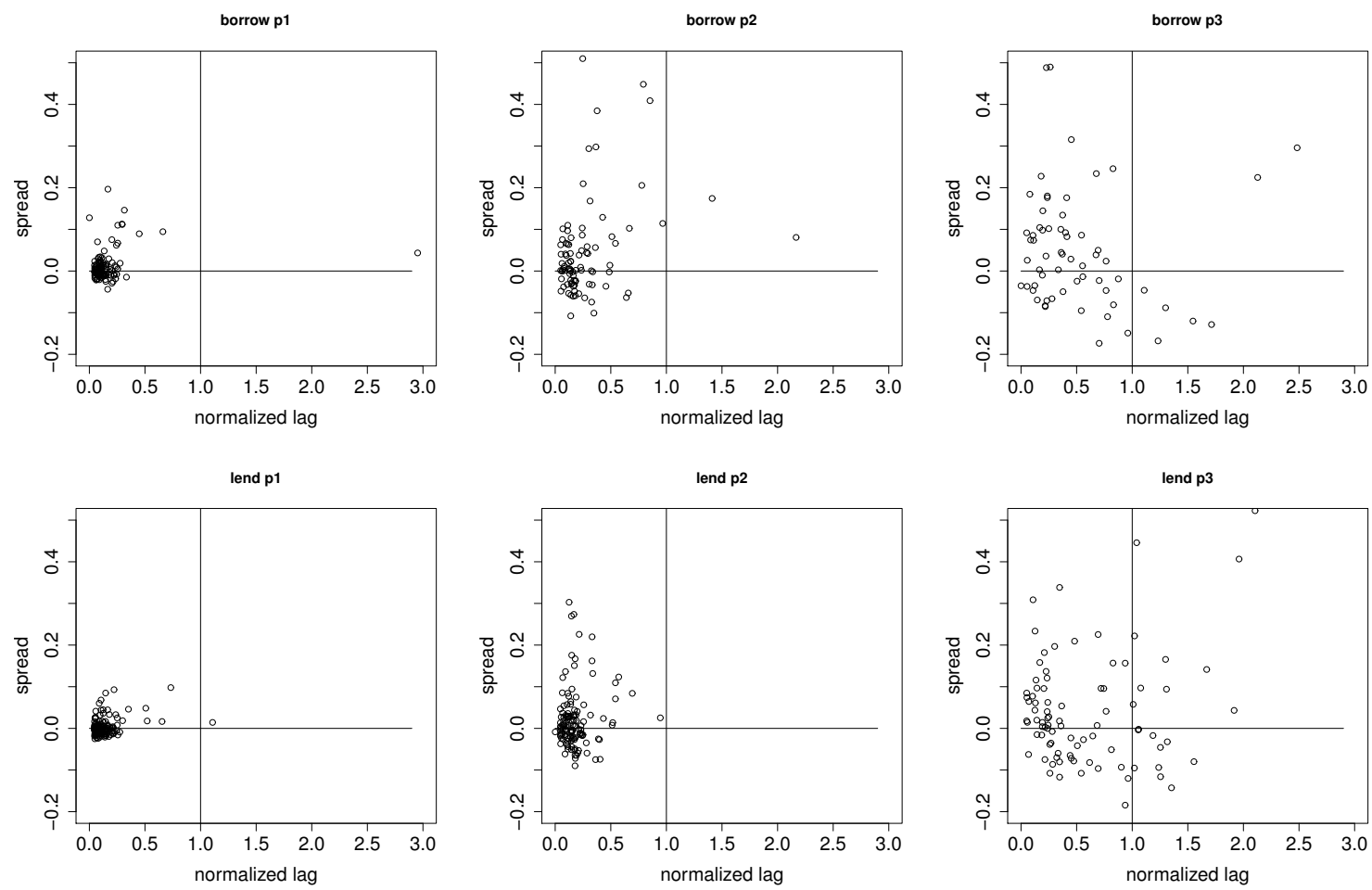

Figure 3: Bank borrowing (top) and lending (bottom) spread ( $y$-axis) versus cut-off lag (normalised by mean participation in the reserve maintenance period, $x$-axis) for Period 1 (pre-crisis, left), Period 2 (subprime crisi, middle), Period 3 (post-crisis, right). 
banks' behaviour either as a borrower or as a lender. We then compare the cut-off point to the bank trading frequency, that is the average number of days a bank is active (as a borrower or as a lender) in a reserve maintenance period.

In Figure 3 we plot, for each bank, the ratio of the bank cut-off point to its trading frequency versus its average credit spread. The horizontal line at 0 and the vertical line at 1 separate the phase space into four regions. The left quadrants Q1 (top) and Q4 (bottom) contain banks whose performance autocorrelation is shorter than a reserve maintenance period, while the right quadrants Q2 (top) and Q3 (bottom) identify banks with a performance autocorrelation longer than a reserve maintenance period. The figure shows that, as the crisis progressed from Period 1 to Period 3, banks' performances became more diversified and banks were locked for longer in their patterns of over- or under-performance. Nonetheless, only very few borrowers and lenders experienced autocorrelations beyond a single reserve maintenance period. If spreads were determined by bank-specific characteristics, such as credit rating or size, or by a consistent strategic behaviour, we would expect to find a long-term autocorrelation in their performance, that is not observable here. Thus, our analysis questions whether banks' spreads may have been affected not only by idiosyncratic factors, in particular credit ones, but also by factors such as the market conditions at the time banks execute their trades.

\section{Explanatory variables and their relationship with interbank spreads}

In this section we identify explanatory variables related to microstructure features that can potentially affect interbank spreads. As shown in the following subsections, four features of the market changed considerably after the beginning of the crisis: the slope of the intraday rate term structure, the market bid-ask spread, the reserve requirement effect and the price impact.

\subsection{Term structure of intraday spreads}

As initially reported by Baglioni and Monticini (2008), trading in the interbank market is more expensive in the morning than in the afternoon. This is due to the implicit intraday maturity of overnight deposits, which are not expected to be reimbursed after 24 hours, but at 9am of the day following the trade (foreign banks were allowed to settle their operations at 12am, but only one did so). Therefore, overnight deposits traded earlier in the morning have a longer maturity and higher expected yields. Baglioni and Monticini (2013) studied the evolution of the intraday term structure during the crisis. They report a considerable increase in the slope of the yield curve after the default of Lehman that may create a risk-free profit opportunity (lend in the morning and borrow in the afternoon). The authors suggest that this opportunity is not arbitraged away after the crisis for two main reasons: uncertainty about the availability of liquidity late in the afternoon and an increase in the implicit cost of collaterals. We calculate the intraday interest rate spread $s_{d}(t)$ as the difference between the instantaneous rates within a window of one hour centered around time $t$ of day $d$ (i.e., considering the trades performed in the 30 minutes before and after $t$ ) and the average rate of that day ${ }^{2}$. Figure 4 shows the average intraday interest rate spread in Period 1, 2 and 3, which is in line with the results of Baglioni and Monticini (2013) ${ }^{3}$

\footnotetext{
${ }^{2}$ Baglioni and Monticini (2013) use the main refinancing rate as reference. We choose to estimate the spread with respect to the average market rate so that the spread is not directly affected by official rates and monetary policy decisions.

${ }^{3}$ Although the market is open $8 \mathrm{am}-6 \mathrm{pm}$, in Figure 4 we consider only the data $9 \mathrm{am}-5 \mathrm{pm}$ because only in Greece and Portugal markets are open 8-9am and 5-6pm.
} 


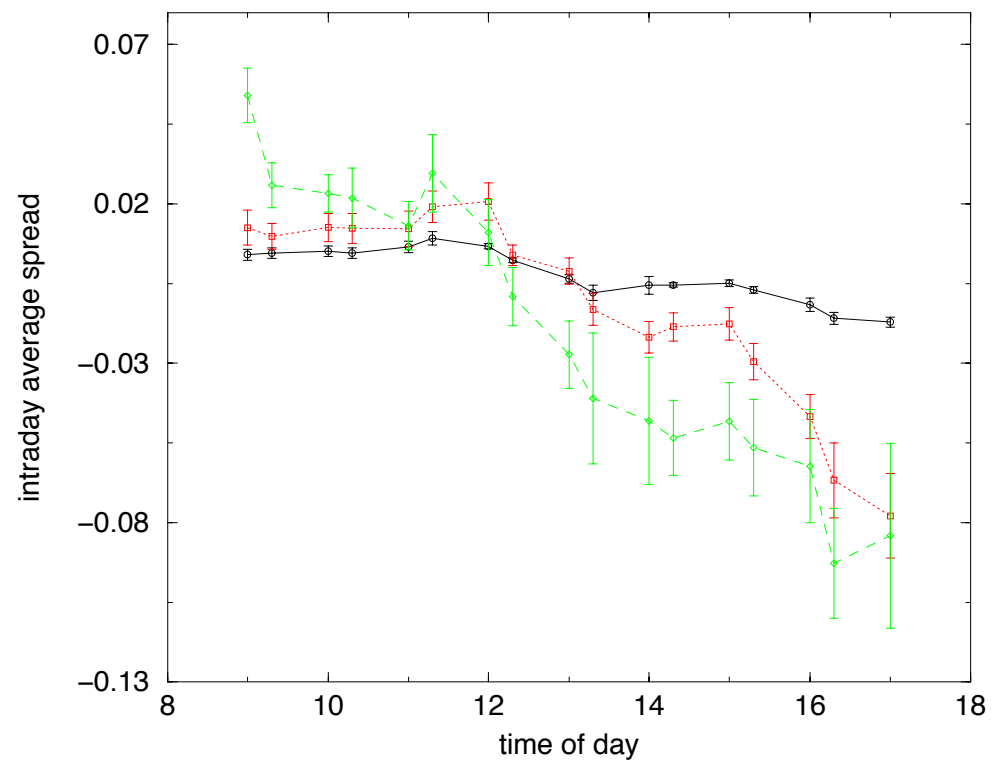

Figure 4: Intraday spread averaged over Period 1 (black circles), Period 2 (red squares) and Period 3 (green diamonds).

The observation of such a slope in the term structure of overnight rates suggests the possibility of an opportunistic behaviour for banks with liquidity surplus: lend in the morning, borrow in the afternoon. Nonetheless such a strategy would entail some risk. In fact a negative slope of the rates was not observed every single day and while the average spread is lower in the afternoon, it is also more volatile as shown by the higher variance bars in Figure 4. Our findings suggest that while the slope of the intraday yield curve did not guarantee arbitrage opportunities, it did create opportunities for risk-oriented banks to profit from the pattern of intraday rates. This raises the interesting question "Are interbank spreads affected by the banks' decisions to trade either in the morning or in the afternoon?".

We answer this question by considering the morning/afternoon $(\mathrm{am} / \mathrm{pm})$ volume imbalance ratio

$$
x_{j, m}^{\mathrm{am} / \mathrm{pm}}=\frac{V_{j, m}^{\mathrm{am}}-V_{j, m}^{\mathrm{pm}}}{V_{j, m}^{\mathrm{am}}+V_{j, m}^{\mathrm{pm}}}=\frac{V_{j, m}^{\mathrm{am}}-V_{j, m}^{\mathrm{pm}}}{V_{j, m}},
$$

where $V_{j, m}^{\text {am }}$ is the volume traded by bank $j$ in the mornings of month $m$ and $V_{j, m}^{\mathrm{pm}}$ is the volume traded by bank $j$ in the afternoons of month $m$. This ratio measures a bank's decision to borrow or to lend money when, on average, the rate is respectively higher or lower.

\subsection{Market bid-ask spread}

Due to missing posted quotes, we construct a proxy of the real bid-ask spread as follows. In each day, following George, Kaul and Nimalendran (1991), we calculate the volume-weighted average rates at which buy-initiated transactions and sell-initiated transactions are settled. We take the difference between these two rates as a proxy of the bid-ask spread. The volume-weighted daily 
average values $r_{d}^{\mathrm{b}}$ and $r_{d}^{\mathrm{s}}$ are defined as

$$
\begin{aligned}
r_{d}^{\mathrm{b}} & =\frac{1}{V_{d}^{\mathrm{b}}} \sum_{j=1}^{N_{d}} \sum_{i=1}^{N_{j, d}^{\mathrm{b}}} V_{i, j, d}^{\mathrm{b}} r_{i, j, d}^{\mathrm{b}} \\
r_{d}^{\mathrm{s}} & =\frac{1}{V_{d}^{\mathrm{s}}} \sum_{j=1}^{N_{d}} \sum_{i=1}^{N_{j, d}^{\mathrm{s}}} V_{i, j, d}^{\mathrm{s}} r_{i, j, d}^{\mathrm{s}},
\end{aligned}
$$

where the superscripts $\mathrm{b}$ and $\mathrm{s}$ label buy and sell transactions.

The bid-ask spread (or sell-buy spread) can now be easily computed as $s_{d}=r_{d}^{\mathrm{b}}-r_{d}^{\mathrm{s}}$. Figure 5 shows the evolution of its monthly average and of its monthly variance. The vertical lines indicate the coordinated intervention of central banks to increase liquidity (August 2007) and the collapse of Lehman Brothers (September 2008). We show the pattern from the introduction of the Euro (1999) to stress the flat dynamics before the financial turmoil. Two very well-defined peaks are clearly present after the crisis milestones.
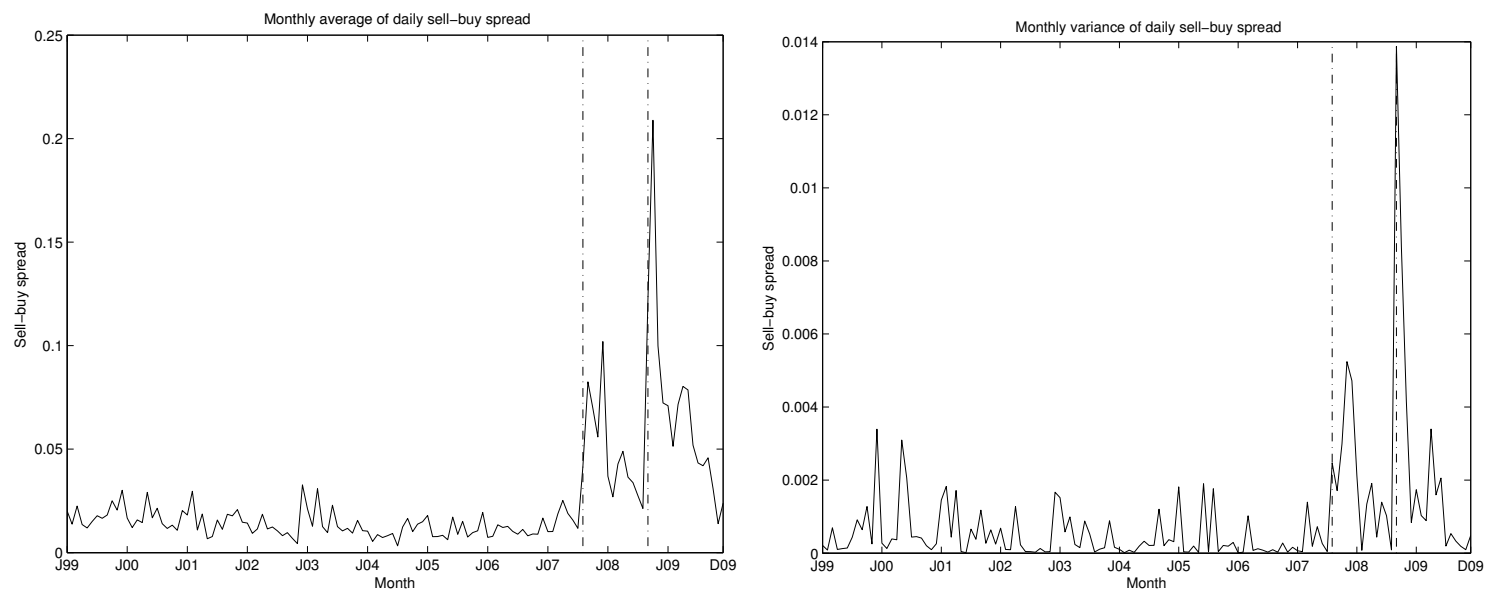

Figure 5: Monthly average (left) and monthly variance (right) of the daily sell-buy spread.

The first conclusion we observe is that the spread has dramatically increased during the crisis and two very well-defined peaks are clearly present in coincidence with the beginning of the crisis and the collapse of Lehman. During the crisis, the bid-ask spreads have experience values above 200 basis points, when the usual pre-crisis level was about 3 basis points. Liquidity stress seems to have been absorbed just before the collapse of Lehman, when the bid-ask spread fell below 5 basis points, the level empirically observed before the sub-prime shock. In both events, the spread trend is absorbed in a few weeks, with a strong correlation with the volatility of rates (Gabbi, 2005). This is certainly due to the massive liquidity intervention of the European Central Bank, which in the period between 2007 and 2018 increased its assets by about 3 trillion euros, using non-conventional monetary policies, such as standing facilities, marginal lending and open market operations. The bid-ask spread effect raises the question: "Can banks trade at a more profitable rate if they submit their orders as quoters rather than as aggressors?" We answer this question by considering as explanatory variable the quoter/aggressor volume imbalance ratio

$$
x_{j, m}^{\mathrm{q} / \mathrm{a}}=\frac{V_{j, m}^{\mathrm{q}}-V_{j, m}^{\mathrm{a}}}{V_{j, m}^{\mathrm{q}}+V_{j, m}^{\mathrm{a}}}=\frac{V_{j, m}^{\mathrm{q}}-V_{j, m}^{\mathrm{a}}}{V_{j, m}},
$$


where $V_{j, m}^{\mathrm{q}}$ is the volume traded by bank $j$ in month $m$ as quoter and $V_{j, m}^{\mathrm{a}}$ is the volume traded by bank $j$ in month $m$ as aggressor. This ratio measures a bank's decision to borrow or to lend money as an aggressor or a quoter.

\subsection{Price impact effect}

Our sample of banks is highly heterogeneous with larger (domestic and foreign) banks trading orders of larger sizes, while smaller banks exchange smaller volumes, as shown in Figure 6.
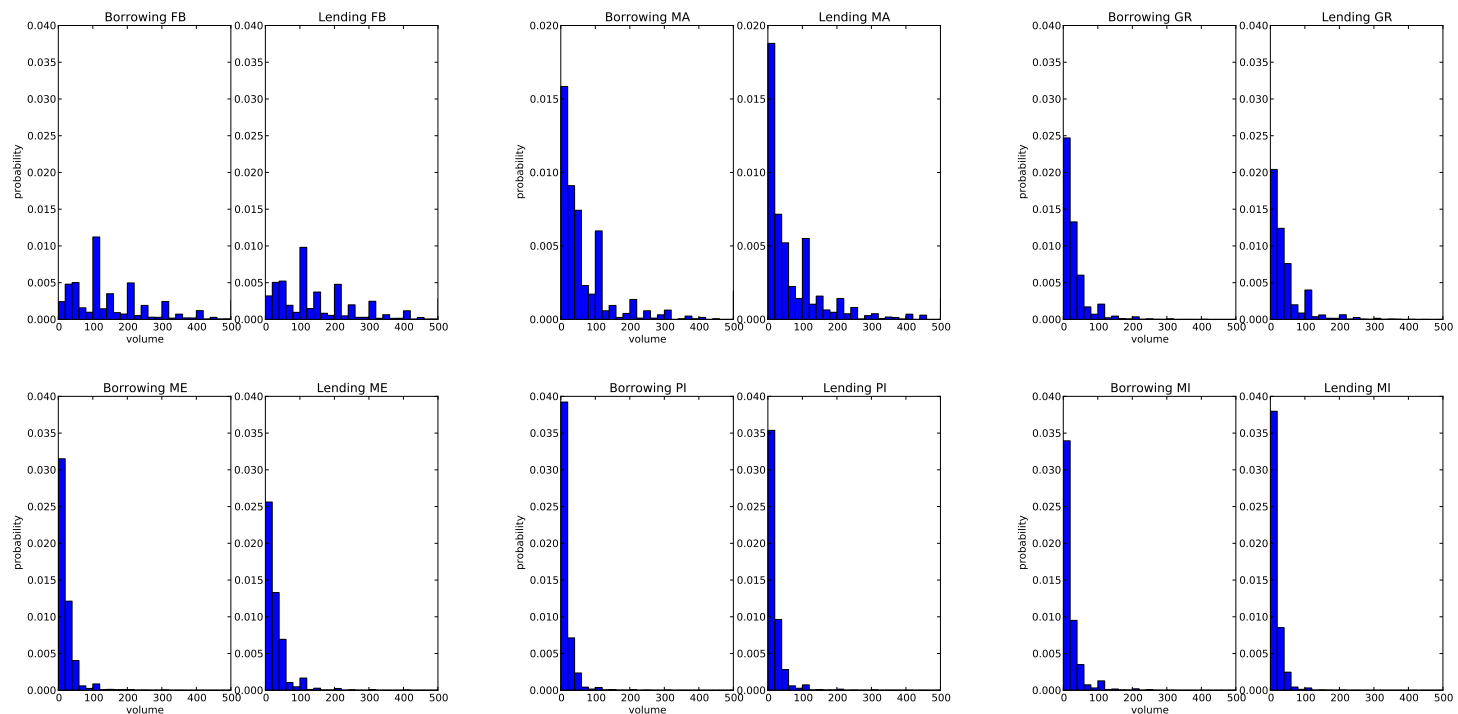

Figure 6: Distribution of order sizes for different groups of banks as borrower (left subpanels) and lenders (right subpanels).

The price-volume hypothesis and market concentration hypothesis have been the subject of many empirical studies in securities markets such as Beaver et al. (1980), Karpoff (1987), Campbell (1993), Rosu (2009). However, the effect of volume on prices has been underestimated in money markets. By investigating the role of market concentration on spreads, we can test if some results that apply to equity and futures market may also be valid for credit markets. More precisely, we want to detect whether the corollary of the efficient market hypothesis, according to which large blocks of assets are traded at close to the market price, applies to the interbank market. The empirical evidence is mixed: in particular, Lamont and Frazzini (2007) suggest that companies with high trading volume concentration perform better in equity market, while Bushman et al. (2011) find that volume concentration is negatively correlated to abnormal spread. During the financial crisis, the role of order size on credit rates could have changed because of the liquidity pressure on banks and the low depth of the interbank market. Including a concentration variable allows us to address the question "Are interbank spreads affected by the size of orders relative to the overall market volume?" We assess this question by considering the concentration ratio

$$
x_{j, m}^{\mathrm{conc}}=\frac{V_{j, m}}{V_{m}},
$$

where $V_{j, m}$ is the volume traded by bank $j$ in month $m$ and $V_{m}=\frac{1}{2} \sum_{j=1}^{N_{j}} V_{j, m}$ is the total volume 
traded in the market in month $m$. The aim of this ratio is to test the impact of order size on spread.

\subsection{Reserve requirement effect}

Some authors have shown that liquidity trading is influenced by the reserve maintenance period announced by the ECB. This is intuitively due to the fact that banks are constrained in governing the average value required by the central bank as the reserve maintenance period approaches. Barucci et al. (2004) and Iori et al. (2008) have provided evidence that the interest rate exhibits predictable patterns at the end of the reserve maintenance period, with a consistent decrease reported at the end of the period before 2001, and a consistent increase after 2001. Gaspar et al. (2008) showed that market activity intensifies over the reserve maintenance period with the number of trades and the realised volatility of the overnight interest rate reaching a peak on the last day of the period; the imbalance between buy and sell orders decreases markedly over the last days; the market spread follows a similar path with a decrease towards the end of the period. Also, during the last days of the period, the deviation of e-MID transaction prices from the actual EONIA rate increases. Such empirical patterns are consistent with theoretical predictions and remain valid across subsamples.

While we do not observe, for the analyzed period, a consistent increase (or decrease) of interbank rates at the end of reserve maintenance periods, we do ask the question "Are interbank spreads affected by banks' trades executed at the end of the reserve maintenance period?" We answer this question by considering the reserve maintenance period ratio

$$
x_{j, m}^{\mathrm{rmp}}=\frac{1}{V_{j, m}} \sum_{d=N_{j, m}-2}^{N_{j, m}} V_{j, d},
$$

i.e. the volume traded by bank $j$ in the last three days of month $m$ divided by the total volume traded by bank $j$ in month $m$.

\section{Methodology and empirical results}

Table 2 reports descriptive statistics for spread and market microstructure variables for borrowers and lenders. The comparison of the different periods, before and after the crisis, allows us to highlight the change in the explaining factors and how they have conditioned the spreads. The borrowing spread lies between -110 and $50 \mathrm{bps}$ with an average value of 0.48 ; the highest average spread was observed during the crisis. The lending spread lies between -118 and 81 bps with an average value of -0.23 . On the borrowing side, while the mean value of the am/pm volume imbalance ratio $x_{j, m}^{\mathrm{am} / \mathrm{pm}}$ is positive, we observe its smallest value in Period 2, indicating that overall at the beginning of the crisis banks postponed some of their borrowing activity to the afternoon, in the attempt to achieve lower rates. After the Lehman default nonetheless borrowing is concentrated in the morning, probably in response to increasing liquidity pressure on banks. On the lending side, $x_{j, m}^{\mathrm{am} / \mathrm{pm}}$ becomes negative in Period 2 suggesting liquidity hoarding in the morning, in response to banks' increased uncertainty about their own liquidity needs. In Period 3 , however, $x_{j, m}^{\mathrm{am} / \mathrm{pm}}$ reverts to positive and reaches its highest value, indicating that lenders are willing to satisfy the high demand from borrowers, that pushed the morning rates to very high values after the default of Lehman. This behaviour may appear surprising because in the post-crisis the ECB offered unlimited amounts of liquidity at fixed rate. Nonetheless central bank borrowing is collateralised and, as reported by Baglioni and Monticini (2013), the implicit cost of collaterals increased considerably during and 
after the crisis. The dynamics of the am/pm volume imbalance ratio suggests that banks found more attractive to borrow in the uncollateralised interbank market after the crisis, and were ready to pay a premium to secure liquidity early in the trading day, rather than provide collaterals to secure central bank financing.

As the crisis progresses, we also note a tendency for borrowers to act more often as quoters. This may depend on the attempt to set the rate a priori in a period of high volatility and increasing spreads. Lastly, we observe an increase in the concentration ratio over time on both sides of the market. The variations of the concentration ratio across the three periods are negligible.

For a bank $j$ executing $N_{j, m}$ transactions on a given reserve maintenance month $m$, the volumeweighted monthly average credit spread is

$$
y_{j, m}=\frac{1}{V_{j, m}} \sum_{d=1}^{N_{j, m}} V_{j, d} c_{j, d}
$$

In our sample we have 42 monthly periods and our regression models in Section 3 rely on monthly data.

To assess the impact of the microstructure features on monthly credit spreads, we performed the following pooled OLS regressions with robust standard errors, separately for borrowing and lending banks:

$$
\begin{aligned}
y_{j, m}= & \beta_{0}+\beta_{1} x_{j, m}^{\mathrm{am} / \mathrm{pm}}+\beta_{2} x_{j, m}^{\mathrm{q} / \mathrm{a}}+\beta_{3} x_{j, m}^{\mathrm{c}}+\beta_{4} x_{j, m}^{\mathrm{rmp}} \\
& +\beta_{5} x_{j}^{\mathrm{SM}}+\beta_{6} x_{j}^{\mathrm{ME}}+\beta_{7} x_{j}^{\mathrm{LA}}+\beta_{8} x_{j}^{\mathrm{MA}}+\beta_{9} x_{j}^{\mathrm{FB}}+u_{j, m},
\end{aligned}
$$

where $u_{j, m}$ is the residual. Bank-specific variables are defined as dummies with six levels (Minor, Small, Medium, Large, Major and Foreign) and the Minor group is chosen as the reference. The asset size information of the foreign banks is not available for us, even though foreign agents, on balance, are large institutions. The model is estimated separately for the three subperiods 1, 2 and 3 defined in Table 1. Results for the baseline regressions are reported for the borrowing banks in Table 3 and for the lending banks in Table 8.

The analysis shows that time of trading is significant and positively correlated with spreads both on the lending and the borrowing side (trading preferentially in the morning improves lender performance and reduces borrower performance) in all three periods. The am/pm volume imbalance ratio $x_{j, m}^{\mathrm{am} / \mathrm{pm}}$ increases over time for both borrowers and lenders, indicating that the effect of timing on trade becomes more determinant with the progression of the crisis.

Trading preferentially as a quoter improves the performance of both lenders and borrowers. The coefficient of quoter/agressor volume increases (in absolute value) as the crisis progresses. These findings suggest that quoters have an advantage in determining interbank rates compared to aggressors. The statistical significance of this variable may be due, in addition to the spread affect, to the information content of order flows. Before the crisis, the purchase of liquidity from an aggressor could have been a signal, with noise, that the aggressor believed the rate was undervalued (Dagfinn, 2003)). After the crisis, the information content may have changed and simply reveal how bank treasuries have to balance inflows and outflows.

Volume concentration is significant, and more important in Period 1 and Period 3 for borrowers, and in Period 2 and Period 3 for lenders. The sign of the Concentration Ratio, positive for borrowers and negative for lenders, indicates that the volume concentration has a lose-lose effect for both agents of the liquidity exchange in the interbank market. This result is consistent with the imperfect substitutes hypothesis (Scholes, 1972, Kraus \& Stoll, 1972, Hess \& Frost, 1982), which assumes 
that assets are not close substitute for each other. In case of large banks, the small number of counterparts and the disclosure of higher risks could have affected the rate of interbank deposits. Therefore, equilibrium rates change when demand curves shift to eliminate excess demand.

The end of the reserve maintenance period is significant for borrowers only after the crisis, when

$x_{j, m}^{\mathrm{rmp}}$ has a positive sign thus supporting the hypothesis that in Period 3 banks were constrained by the reserve requirement. The reserve maintenance period ratio is significant for lenders before and during the crisis. The negative sign indicates that hoarding liquidity and postponing lending till the end of the maintenance period, was not a profitable strategy for lenders, at least before the Lehman default.

We confirm that size is an important variable in the determination of the interbank rate with borrowing rates decreasing, on average, and lending rates increasing with banks size. The size effect is particularly strong for borrowers in Period 3. Nonetheless, size is not significant in Period 2, except for the major banks. This result indicates that when market microstructure variables are controlled for, size is not as determinant as previously reported in the literature (Angelini et al. 2011, Gabrieli 2012).

Foreign banks (that in this market are typically large), pay higher spreads than the larger Italian banks as borrowers, and receive lower spreads as lenders, as a result suggesting poor market integration in the European interbank market.

The F-test statistics reported at the bottom of in Table 3 and Table 8 check whether the coefficients of the market microstructure variables are jointly equal to zero or not. The statistics indicate that microstructure variables are jointly significant and enhance the explanatory power of the model.

Overall, our analysis demonstrates that spreads incorporate a liquidity risk premium (the widening bid-ask spreads and the increasing intraday slope of interest rates are indicators of liquidity shortages) in addition to a credit risk premium (that previous studies have associated with bank sizes). This corroborates the analyses of Michaud and Upper (2008) and Eisenschmidt and Tapking (2009), which point out that after August 2007 rates reached levels that cannot be explained alone by a higher credit risk.

\subsection{Robustness checks}

Our first robustness check aims to control for potential self-selection problem due to the drop in the number of banks trading in the e-MID market after the collapse of Lehman Brothers. Therefore, we estimate the same model as above for three different sub samples of banks. Firstly, we consider only banks which have traded at least 25 times in each of the three periods, secondly we consider the banks which have traded at least 50 times in each of the three period and lastly, we consider all banks in the sample but control for the banks that dropped out after the collapse of Lehman Brothers with a dummy variable (Period 3). The findings, reported in Table 3 for borrower and Table 8 for lenders indicate that the baseline regression results remain virtually unchanged and robust to the different samples of the dataset. Moreover, banks that drop in Period 3 do not appear to borrow at significantly different rates compared to the banks that remain active, suggesting that the selfselection problem is not an issue for our analysis. On the lending side nonetheless the banks that dropped in Period 3 received consistently lower rates than the banks which remained. This may be a consequence to the injection of liquidity by the ECB after the Lehman default that possibly limited profitable lending opportunities in the interbank market. A similar impact has been confirmed by Barucca and Lillo (2018) during the period when the ECB adopted a particularly expansionary policy with LTRO operations.

A second check is based on bank-fixed effects capturing bank characteristics such as ownership 
and credit risk. The time-fixed effect captures the evolution of the market across time and common shocks that can affect all banks. While fixed effect models do not allow to estimate the coefficients for dummy variables (such as size), they provide the opportunity to check whether pooled OLS analysis gives similar results to the fixed effect model when only market microstructure variables are considered. We use the following panel data model with time and bank fixed effects and robust standard errors:

$$
\begin{gathered}
y_{j, m}=\beta_{0}+\beta_{1} x_{1, j, m}+\beta_{2} x_{2, j, m}+\beta_{3} x_{3, j, m}+\beta_{4} x_{4, j, m}+u_{j, m} \\
u_{j, m}=u_{m}+\delta_{m}+\varepsilon_{j, m} .
\end{gathered}
$$

The results reported in Table 4 for borrowers and in Table 9 for lenders show that, even when controlling for bank heterogeneity, the relation between spreads and market microstructure variables remain unchanged respect to the baseline regression model ${ }^{4}$

\subsection{The relevance of microstructure factors}

In this section, we capture the role of the microstructure variables separately for each group, in terms of their asset size and nationality. To reduce the number of tables we report results only for the three periods combined together. Also in this case we estimate the baseline regression for all transactions and perform robustness checks with different samples of banks. The results are reported in Table 5 for borrowers and Table 10 for lenders.

On the demand side, the time of trading is statistically significant and positive for all groups of banks, indicating that all banks benefit from borrowing later in the day. Acting as a quoter is again significant for all groups. Banks achieve lower borrowing rates when trading on this side of the market. However, the quoter/aggressor volume imbalance ratio is negative but insignificant for major borrowers. This is possibly due to the fact that the major banks consistently execute more than $75 \%$ of their trades as quoters, thus the quoter/aggressor volume imbalance ratio has little variability for this group.

On the supply side, lending in the morning and lending as a quoter leads to higher returns for all groups of banks. Nonetheless, the quoter/aggressor volume imbalance ratio is not significant for foreign banks. The fact that foreign banks do not achieve better rates when trading as quoters again suggests poor market integration, which also leads a lower capability to act strategically within the market. The interbank market gradually disintegrated after the start of the crisis. Banks have also started to favour domestic counterparties as a result of bail out decisions favouring creditors of the same citizenship.

When controlling for banks that drop in Period 3, we find that this variable is not significant as a determinant of the lending rates. On the borrowing side instead our analysis interestingly suggests that the smaller banks (SM and MI groups) that dropped, while still in the market significantly outperformed the banks that remained active after the Lehman default. On the contrary, the large banks that dropped significantly underperformed, in Period 1 and Period 2, the banks that kept trading in Period 3. Thus, if there was a self-selection issue, the reasons for leaving the e-MID market may have been different for banks belonging to groups of different size: adverse selection for the small banks, as suggested by Heider et al. (2015), and a stigma effect associated with signalling financial distress for the larger ones.

\footnotetext{
${ }^{4}$ Temiszoy et al. (2015), performing link-level rather than bank-level regressions, and show that the effect of the microstructure variable is qualitatively the same also when controlling for the identity of the counterparty to a trade as well as when including indices of preferential lending and borrowing among the regression variables.
} 


\subsection{Banks' behaviour}

The aim of this section is to establish whether some banks were able to make profit more than others exploiting the changing microstructure conditions and trading more strategically. In particular, we focus on the am/pm volume imbalance ratio $x_{j, m}^{\mathrm{am} / \mathrm{pm}}$ and the quoter/aggressor volume imbalance ratio $x_{j, m}^{\mathrm{q} / \mathrm{a}}$. We treat them as the dependent variables, and test whether their values changed significantly across groups and in which direction.

We estimate the following pooled OLS model with robust standard errors, separately for borrowers and lenders:

$$
\begin{gathered}
x_{j, m}^{\mathrm{am} / \mathrm{pm}}=\beta_{0}+\beta_{1} x_{j}^{\mathrm{SM}}+\beta_{2} x_{j}^{\mathrm{ME}}+\beta_{3} x_{j}^{\mathrm{LA}}+\beta_{4} x_{j}^{\mathrm{MA}}+\beta_{5} x_{j}^{\mathrm{FB}}+u_{j, m} \\
x_{j, m}^{\mathrm{q} / \mathrm{a}}=\beta_{0}+\beta_{1} x_{j}^{\mathrm{SM}}+\beta_{2} x_{j}^{\mathrm{ME}}+\beta_{3} x_{j}^{\mathrm{LA}}+\beta_{4} x_{j}^{\mathrm{MA}}+\beta_{5} x_{j}^{\mathrm{FB}}+u_{j, m} .
\end{gathered}
$$

The regression outputs reported in Table 6 for borrowers indicate that only major and foreign borrowers performed the majority of their trades in the afternoon. While both groups increased the proportion of afternoon trades in Period 2, only major banks increased it even further in Period 3. Foreign banks did not manage to do so and reverted to the pre-crisis level of afternoon trading in Period 3. The positive and significant coefficients for the minor banks reveal on the contrary that they mainly borrowed in the morning, thus paying higher rates. On the lending side, as reported in Table 11, minor banks lend preferentially in the morning, achieving higher rates, and foreign banks in the afternoon, achieving lower rates. Overall there is a tendency to hoard liquidity in the morning in Period 2.

The sign of the coefficients of the quoter/aggressor volume imbalance ratio reported in Table 7 for borrowers and in Table 12 for lenders reveals that, apart from the minor banks, borrowers prefer to trade as quoters and lenders prefer to trade as aggressors. On the lending side the effect becomes even more clear with the progression of the crisis. The larger Italian banks and the foreign banks achieved the largest proportion of borrowing trades as quoters thus achieving better rates. On the lending side the major banks achieved the largest proportion of trades as quoters in Period 1 and Period 2, but in Period 3 it was the minor and small banks which traded more often as aggressors.

Our findings indicate that, in addition to the too-big-to-fail argument, the favourable borrowing and lending conditions of larger banks have partly been the result of a wiser liquidity management. On the lending side we observe that foreign banks have not been able to optimise their strategies: small or negative am/pm and quoter/aggressor volume imbalance ratios indicate too much lending in the afternoon and as aggressors, both of which is less profitable. As mentioned by Cassola et al. (2010), this observation confirms a poor market integration on this side of the market, with foreign banks lending mostly to other foreign and large Italian banks that, as seen before, tend to borrow later in the afternoon.

\section{Conclusions}

We have investigated the impact of the financial crisis on the behaviour of banks within the electronic interbank market and, in turn, the drivers after the turmoil over the lending and borrowing spreads. Running econometric analyses we have highlighted the role of the changing intraday term structure of the interest rate and of the market bid-ask spread as explanatory variables for the variability in credit conditions. In particular our results show that the higher the volume traded by a bank in the morning, the higher the spreads (that is borrowing conditions deteriorate in the morning for borrowers and improve for lenders) and the higher the volume traded as quoters, the better the 
rates obtained, both for lenders and borrowers.

While our analysis confirms that larger banks did perform better during the crisis, we identify the reasons for their success. The larger banks responded better to the changing market microstructure condition and optimised their trades to reduce the liquidity costs. Their stronger performance was actively achieved by a sophisticated liquidity management and not just the result of the market participants perceiving them as too big to fail. Our empirical results confirm that the Euro interbank market after the crisis became more competitive, differentiating banks behaviours. With a more intense competition, according to the theoretical model introduced by Carletti and Leonello (2018), the probability of a banking crisis should now be lower. The policy implications of our findings are as follows.

To reduce the volatility of interbank market rates, central banks should provide liquidity by calibrating their interventions according to the slope of the intraday term structure. Since this slope depends on expected short rates, central banks can fine-tune how they provide liquidity playing as market makers continuously during the trading day, coherently with the real-time gross settlement of the payment system.

The interest rate volatility stabilization and spread normalization could be pursued introducing overnight deposits expiring after 24 hours. This way the liquidity settlement would be distributed along the day, avoiding the concentration of all the interbank trades early in the morning. This innovation could go along with the introduction of intraday deposits, completing the Arrow-Debreu market structure.

Finally, the evidence about the dependence of interest-rate spreads on banks' behavior supports a revision of their liquidity-management practice. Banks' treasury departments should try to manage and net their financial balances by optimizing costs and returns according to the features of the market microstructure, such as timing their trades, adjusting the concentrations of volumes, possibly via pooling operations, and choosing the quoter/aggressor side to lend and borrow money.

\section{Acknowledgments}

Funding was provided by the European Union (Grant No. 255987) and, for the Systemic Risk Centre, by the Economic and Social Research Council (ESRC, Grant No. ES/K002309/1). 


\section{References}

[1] Acharya, V. V., and Merrouche, O. 2013. Precautionary hoarding of liquidity and inter-bank markets: Evidence from the sub-prime crisis. Review of Finance 17(1), 107-160.

[2] Angelini, P. Nobili, A. and Picillo, C. 2011. The interbank market after August 2007: What has changed and why? Journal of Money, Credit and Banking 43(5), 923-958.

[3] Baglioni, A. and Monticini, A. 2008. The intraday price of money: evidence from the e-MID interbank market. Journal of Money, Credit and Banking 40(7), 1533-1540.

[4] Baglioni A. and Monticini, A. 2013. Why does the interest rate decline over the day? Evidence from the liquidity crisis. Journal of Financial Services Research 44(2), 175-186.

[5] Barucca, P. and F. Lillo. 2018. The organization of the interbank network and how ECB unconventional measures affected the e-MID overnight market. Computational Management Science 15(1), 33-53.

[6] Barucci, E., Impenna, C. and Renò, R. 2004. The Italian overnight market: Microstructure effects, the martingale hypothesis and the payment system, in M. Bagella, L. Bechetti, I. Hasan and W. C. Hunter (eds.), Monetary Integration, Markets and Regulations - Research in Banking and Finance 4, Elsevier, pp. 319-360.

[7] Beaupain, R. and Durré, A. 2008. The interday and intraday patterns of the overnight market. Evidence from an electronic platform, European Central Bank Working Paper 988.

[8] Beaver, W. H., Lambert, R. A. and Morse, D. 1980. The information content of security prices. Journal of Accounting and Economics 2(1), 3-28.

[9] Berardi, S. and Tedeschi, G. 2017. From banks' strategies to financial (in)stability. International Review of Economics \& Finance 47, 255-272.

[10] Brousseau, V. and Manzanares, A. 2005. A look at intraday frictions in the Euro Area overnight deposit market. European Central Bank Working Paper 439.

[11] Brunetti, H., Harris, J. F., Mankad, S. and Michailidis, G. 2015. Interconnectedness in the interbank market. FEDS Working Paper 2015-090, SSRN 2674602.

[12] Bushman, R. M., McDermott, K. E. and Williams, C. D. 2012. The earnings announcement premium and volume concentration. Kenan-Flagler Business School Working Paper, University of North Carolina at Chapel Hill.

[13] Campbell, J. Y. 1993. Intertemporal asset pricing without consumption data. American Economic Review 83(3), 487-512.

[14] Carletti E., and Leonello, A. 2018. Credit Market Competition and Liquidity Crises. Review of Finance, in press, DOI 10.1093/rof/rfy026.

[15] Cassola, N., Holthausen, C. and Duca, M. L. 2010. The 2007/2008 turmoil: A challenge for the integration of the Euro area money market. European Central Bank Working Paper.

[16] Dagfinn, R. 2003. New electronic trading systems in the foreign exchange market. I: New Economy Handbook, 471-504 
[17] Eisenschmidt, J. and Tapking, J. 2009. Liquidity risk premia in unsecured interbank money markets. European Central Bank Working Paper 1025.

[18] European Central Bank. 2011. Annual Report. https://www.ecb.europa.eu/pub/pdf/annrep/ar2011en.pdf

[19] Finger, K., Fricke, D. and Lux, T. 2013. Network analysis of the e-MID overnight money market: The informational value of different aggregation levels for intrinsic dynamic processes. Computational Management Science 10(2), 187-2011.

[20] Furfine, C. H. 2000. Interbank payments and the daily federal funds rate, Journal of Monetary Economics 46(2), 535-553.

[21] Furfine, C. H. 2001. Banks as monitors of other banks: Evidence from the overnight federal funds market, Journal of Business 74(1), 33-57.

[22] Furfine, C. H. 2002. The interbank market during a crisis, European Economic Review 46(4-5), 809-820.

[23] Gabbi, G. 2005. Semi-correlations as a tool for geographical and sector asset allocation. European Journal of Finance, 11(3), 271-281.

[24] Gabrieli S. 2012. Too-interconnected versus too-big-to-fail: Banks' network centrality and overnight interest rates. Banque de France Working Paper 398.

[25] Galbiati, M., Delpini, D. and Battiston, S. 2013. The power to control. Nature Physics 9(3), $126-128$.

[26] Gale, D. and Yorulmazer, T. 2011. Liquidity hoarding. Federal Reserve Bank of New York Working Paper 488.

[27] Gaspar, V., Quiros G. P. and Mendizabal, H. R. 2008. Interest rate dispersion and volatility in the market for daily funds, European Economic Review 52(3), 413-440.

[28] George, T. J., Kaul G. and Nimalendran M. 1991. Estimation of the bidask spread and its components: A new approach. Review of Financial Studies, 4(4), 623-656.

[29] Hamilton, J. 1996. The daily market for federal funds, Journal of Economic Dynamics and Control 104(1), 26-56.

[30] Heider, F., Hoerova, M., and Holthausen, C. 2015. Liquidity hoarding and interbank market spreads: The role of counterparty risk. Journal of Financial Economics 118(2), 336-354.

[31] Hess, A. C. and Frost, P. A. 1982. Tests for price effects of new issues of seasoned securities. Journal of Finance 37(1), 11-25.

[32] Iazzetta, C. and Manna, M. 2009. The topology of the interbank market: Developments in Italy since 1990. Bank of Italy Working Paper 711.

[33] Iori, G., Renò, R., de Masi. G. and Caldarelli, G. 2006. Trading strategies in the Italian interbank market. Physica A: Statistical Mechanics and its Applications 376(1), 467-479.

[34] Iori, G., De Masi, G., Ovidiu, V. P., Gabbi, G. and Caldarelli, G. 2008. A network of the Italian overnight money market, Journal of Economic Dynamics and Control 32(1), 259-278. 
[35] Iori, G., Mantegna, R. N., Marotta, L., Micciché, S., Porter, J. and Tumminello, M. 2015a. Networked relationships in the e-MID interbank market: A trading model with memory. Journal of Economic Dynamics and Control 50(C), 98-116.

[36] Iori, G., Kapar, B. and Olmo, J. 2015b. Bank characteristics and the interbank money market: A distributional approach. Studies in Nonlinear Dynamics \& Econometrics 19(3), 249-283.

[37] Iori, G., Politi, M., Germano, G. and Gabbi, G. 2015c. Banks' strategies and cost of money: Effects of the financial crisis on the European electronic overnight interbank market. Journal of Financial Management, Markets and Institutions 3(2), 179-202.

[38] Karpoff, J. M. 1987. The relation between price changes and trading volume: a survey. Journal of Financial and Quantitative Analysis 22(1), 109-126.

[39] Kraus, A. and Stoll, H. R. 1972. Price impacts of block trading on the New York Stock Exchange. Journal of Finance 27(3), 569-588.

[40] Lamont, O. and Frazzini, A. 2007. The earnings announcement premium and trading volume. NBER Working Paper 13090.

[41] Michaud, F.-L., and Upper, C. 2008. What drives interbank rates? Evidence from the Libor panel. BIS Quarterly Review.

[42] Rosu, I. 2009. A dynamic model of the limit order book. Review of Financial Studies 22(11), $4601-4641$.

[43] Scholes, M. S. 1972. The market for securities: Substitution versus price pressure and the effects of information on share prices. Journal of Business 45(2), 179-211.

[44] Schwarz, K. 2018. Mind the gap: disentangling credit and liquidity in risk spreads. Working Paper, Wharton School.

[45] Tedeschi, G., Recchioni, M. C., and Berardi S. 2018. An approach to identifying micro behavior: How banks strategies influence financial cycles. Journal of Economic Behavior \& Organization, in press, DOI 10.1016/j.jebo.2018.12.022.

[46] Temizsoy, A., Iori, G. and Montes-Rojas, G. 2015. The role of bank relationships in the interbank market. Journal of Economic Dynamics and Control 59, 118-141. 
Table 2: Descriptive statistics.

\begin{tabular}{ll|cccc|cccc}
\hline \hline & & \multicolumn{9}{|c|}{ Borrower } & \multicolumn{4}{c}{ Lender } \\
\hline Variable & & All periods & Period 1 & Period 2 & Period 3 & All Periods & Period 1 & Period 2 & Period 3 \\
\hline Volume-weighted monthly & Mean & 0.48 & 0.05 & 1.04 & 0.15 & -0.23 & -0.40 & -0.49 & 0.37 \\
average credit spread & Std dev & 7.19 & 3.12 & 7.65 & 9.78 & 8.17 & 4.50 & 9.11 & 9.95 \\
& Min & -110.1 & -41.3 & -110.1 & -84.4 & -118.4 & -97 & -118.4 & -44.7 \\
& Max & 50.1 & 40.6 & 39.6 & 50.1 & 81.9 & 13.4 & 45.3 & 81.9 \\
& Median & 0.25 & 0.18 & 0.83 & -0.49 & -0.12 & -0.12 & 0.007 & -0.78 \\
\hline Am/pm volume & Mean & 0.16 & 0.15 & 0.12 & 0.25 & 0.06 & 0.04 & -0.015 & 0.22 \\
imbalance ratio & Std dev & 0.67 & 0.64 & 0.68 & 0.69 & 0.65 & 0.63 & 0.65 & 0.66 \\
& Min & -1 & -1 & -1 & -1 & 1 & -1 & -1 & -1 \\
& Max & 1 & 1 & 1 & 1 & 1 & 1 & 1 & 1 \\
& Median & 0.32 & 0.29 & 0.25 & 0.43 & 0.19 & 0.14 & 0.08 & 0.40 \\
\hline Quoter/aggressor volume & Mean & 0.31 & 0.28 & 0.28 & 0.42 & -0.62 & -0.59 & -0.63 & -0.66 \\
imbalance ratio & Std dev & 0.69 & 0.68 & 0.70 & 0.67 & 0.50 & 0.51 & 0.49 & 0.51 \\
& Min & -1 & -1 & -1 & -1 & -1 & -1 & -1 & -1 \\
& Max & 1 & 1 & 1 & 1 & 1 & 1 & 1 & 1 \\
& Median & 0.57 & 0.54 & 0.52 & 0.69 & -0.89 & -0.84 & -0.87 & -0.96 \\
\hline Concentration ratio & Mean & 0.0098 & 0.0083 & 0.0091 & 0.0128 & 0.0075 & 0.0066 & 0.0069 & 0.0096 \\
& Std dev & 0.0187 & 0.0154 & 0.0157 & 0.0256 & 0.0129 & 0.0112 & 0.0111 & 0.0169 \\
& Min & $7 \mathrm{e}-07$ & $9 \mathrm{e}-06$ & $7 \mathrm{e}-06$ & $2 \mathrm{e}-06$ & $6 \mathrm{e}-06$ & $6 \mathrm{e}-07$ & $1 \mathrm{e}-06$ & $4 \mathrm{c}-06$ \\
& Max & 0.2177 & 0.1877 & 0.1374 & 0.2177 & 0.2239 & 0.0997 & 0.1046 & 0.2239 \\
& Median & 0.0025 & 0.0020 & 0.0027 & 0.0033 & 0.0028 & 0.0022 & 0.0026 & 0.0040 \\
\hline Reserve maintenance & Mean & 0.17 & 0.16 & 0.16 & 0.17 & 0.19 & 0.19 & 0.20 & 0.18 \\
period ratio & Std dev & 0.24 & 0.22 & 0.23 & 0.26 & 0.24 & 0.23 & 0.24 & 0.25 \\
& Min & 0 & 0 & 0 & 0 & 0 & 0 & 0 & 0 \\
& Max & 1 & 1 & 1 & 1 & 1 & 1 & 1 & 1 \\
& Median & 0.09 & 0.10 & 0.10 & 0.07 & 0.12 & 0.13 & 0.13 & 0.10 \\
\hline \hline
\end{tabular}

Table 3: $t$-test $p$-values for Table 2 .

\begin{tabular}{l|ccc|ccc}
\hline \hline & \multicolumn{3}{|c|}{ Borrower } & \multicolumn{3}{c}{ Lender } \\
\hline Variable & Periods 1-2 & Periods 2-3 & Periods 1-3 & Periods 1-2 & Periods 2-3 & Periods 1-3 \\
\hline Average credit spread & $\mathbf{0 . 0 0}$ & $\mathbf{0 . 0 0}$ & 0.70 & 0.70 & $\mathbf{0 . 0 0}$ & $\mathbf{0 . 0 0}$ \\
am/pm imbalance ratio & 0.31 & $\mathbf{0 . 0 0}$ & $\mathbf{0 . 0 0}$ & $\mathbf{0 . 0 0}$ & $\mathbf{0 . 0 0}$ & $\mathbf{0 . 0 0}$ \\
q/a imbalance ratio & 0.98 & $\mathbf{0 . 0 0}$ & $\mathbf{0 . 0 0}$ & $\mathbf{0 . 0 3}$ & 0.07 & $\mathbf{0 . 0 0}$ \\
Concentration ratio & 0.13 & $\mathbf{0 . 0 0}$ & $\mathbf{0 . 0 0}$ & 0.31 & $\mathbf{0 . 0 0}$ & $\mathbf{0 . 0 0}$ \\
Reserve period ratio & 0.92 & 0.38 & 0.34 & 0.41 & $\mathbf{0 . 0 3}$ & 0.16 \\
\hline \hline
\end{tabular}


Table 4: Pooled OLS results for borrowers.

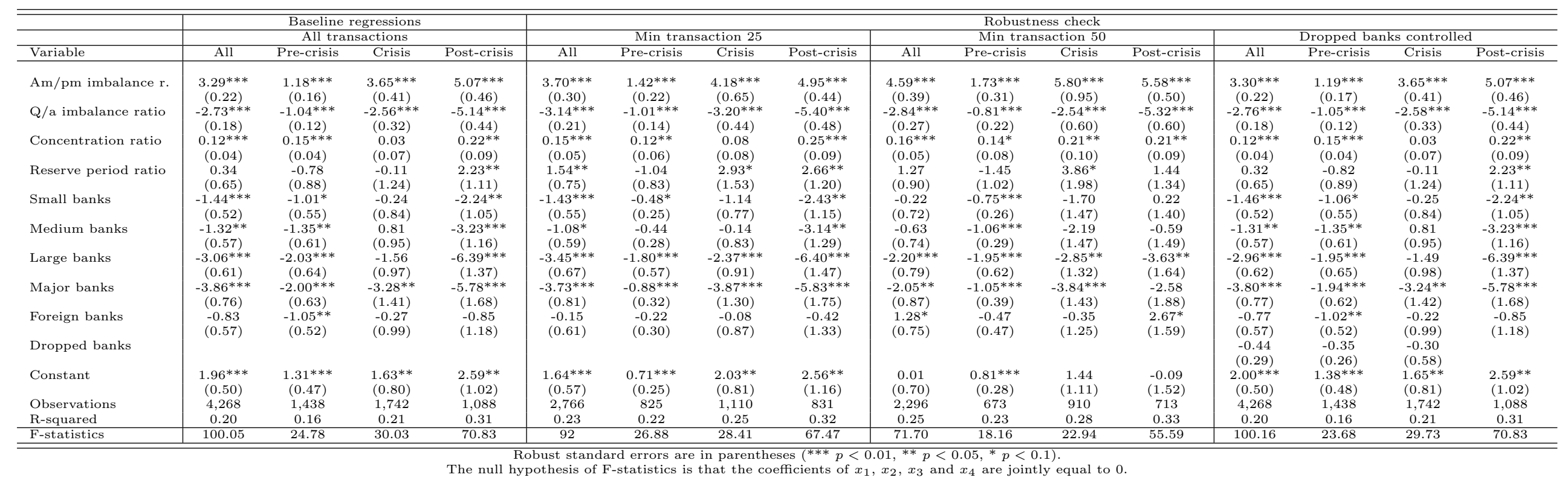

Table 5: Fixed-effect model for borrowers.

\begin{tabular}{|c|c|c|c|c|c|c|c|c|c|c|c|c|c|c|c|c|}
\hline & \multicolumn{4}{|c|}{ 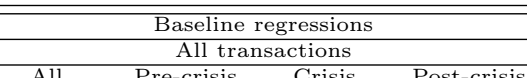 } & \multicolumn{12}{|c|}{ 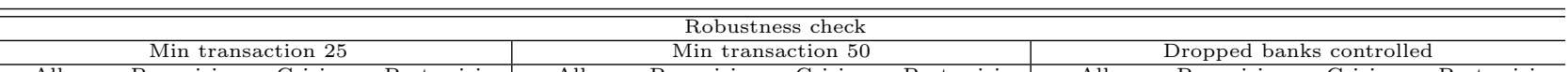 } \\
\hline $\begin{array}{l}\text { Variable } \\
\mathrm{Am} / \mathrm{pm} \text { imalanc }\end{array}$ & & 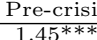 & $\begin{array}{l}\frac{C}{C r i s i s} \\
34 * *\end{array}$ & 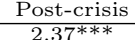 & & $\begin{array}{l}\text { Pre-crisis } \\
163 * *\end{array}$ & 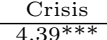 & & & 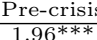 & & -cri & & & & \\
\hline (2) & $\begin{array}{l}(0.29) \\
(0.29 x\end{array}$ & $\frac{0.28)}{(0.28 x}$ & $(0.61)$ & 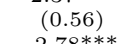 & $(0.45)$ & $(0.40)$ & $(1.14)$ & 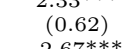 & $(0.57)$ & $(0.55)$ & (1.65) & (0.63) & (2.2.29) & $(0.28)$ & 先.61) & $\begin{array}{l}2.3 .7 .64) \\
(0.56)\end{array}$ \\
\hline & $\begin{array}{l}-1.0 .32) \\
(0.32)\end{array}$ & ${ }_{(0.29)}$ & $\begin{array}{l}-10.53) \\
\left(0_{0.53}\right.\end{array}$ & 年.46) & 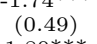 & $(0.51)$ & $(0.86)$ & $(0.62)$ & $\begin{array}{l}-1.60) \\
(0.60)\end{array}$ & $(0.67)$ & (1.01) & $\begin{array}{l}2.0 .67) \\
(0.07)\end{array}$ & (0.32) & (0.29) & $\begin{array}{l}2.0 .53) \\
(0.53)\end{array}$ & $\begin{array}{l}-2.78 * 4 * * \\
(0.46)\end{array}$ \\
\hline cicentration ratio & (0.63) & $\begin{array}{l}-1.088 \\
(0.811)\end{array}$ & $\begin{array}{l}0.06) \\
(1.36)\end{array}$ & 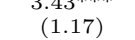 & $\begin{array}{l}1.8 .56) \\
(0.56)\end{array}$ & $\begin{array}{l}\text { (o.64) } \\
(0.64)\end{array}$ & $\begin{array}{l}3.59) \\
(1.59)\end{array}$ & (1.04) & $\begin{array}{l}1.461) \\
(0.61)\end{array}$ & $\begin{array}{l}-(.04) \\
(0.73)\end{array}$ & 资.21) & $\begin{array}{l}2.25 .94) \\
(0.94)\end{array}$ & $\begin{array}{l}(.66) \\
(0.63)\end{array}$ & $(0.81)$ & 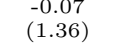 & (1.17) \\
\hline erve period ratio & 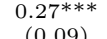 & $\begin{array}{l}0.033 \\
0.052\end{array}$ & $0.077^{* * *}$ & 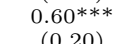 & & 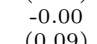 & $\begin{array}{l}0.20 \\
0.25\end{array}$ & $\begin{array}{l}0.56^{* 2 * * *} \\
0.20\end{array}$ & $\begin{array}{l}0.27^{* * *} \\
0.11\end{array}$ & 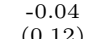 & 0 & $0.54^{* *}$ & $\begin{array}{l}0.27 * * * \\
0.209\end{array}$ & 0.03 & $0.077^{* * 1}$ & 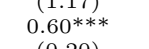 \\
\hline vations & $\begin{array}{l}4,268 \\
4.68\end{array}$ & $\begin{array}{l}1,438 \\
1,438\end{array}$ & 1.7472 & $\begin{array}{l}1,088 \\
1,088\end{array}$ & 2,766 & 825 & 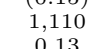 & 831 & $\begin{array}{l}2,296 \\
2,296\end{array}$ & 673 & $\begin{array}{l}910 \\
910 \\
017\end{array}$ & 713 & $\begin{array}{l}4,268 \\
4,268\end{array}$ & 1,038 & 1,742 & 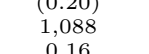 \\
\hline 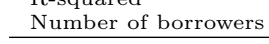 & & & & & & & & ${ }_{74}$ & o & 59 & . & 59 & ${ }_{182}$ & 163 & 166 & 136 \\
\hline
\end{tabular}

Table 6: Pooled OLS results for different groups of borrowers.

\begin{tabular}{|c|c|c|c|c|c|c|c|c|c|c|c|c|c|c|c|c|c|c|}
\hline & \multirow{2}{*}{\multicolumn{6}{|c|}{$\begin{array}{l}\text { Baseline legressions } \\
\text { All transactions } \\
\text { um bank } \\
\text { All large }\end{array}$}} & & & & & & & \multirow{2}{*}{\multicolumn{6}{|c|}{$\begin{array}{l}\text { Robustness check } \\
\text { Min transaction } 50 \\
\text { Din trats }\end{array}$}} \\
\hline $\begin{array}{l}\text { Variable } \\
\text { Ambalance }\end{array}$ & $\begin{array}{l}\text { Alll mininor banks } \\
\text { not }\end{array}$ & & & & & II foreign banks & 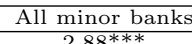 & 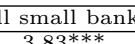 & 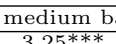 & 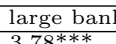 & 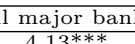 & 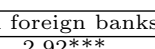 & & & & $\frac{8<* *}{60 * *}$ & 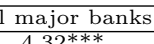 & \\
\hline Q/a imbalance ratio & 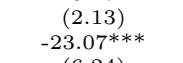 & 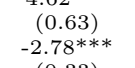 & 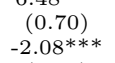 & 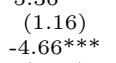 & 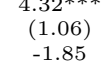 & 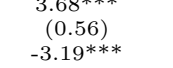 & 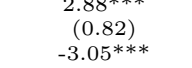 & 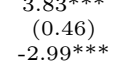 & 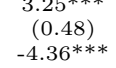 & 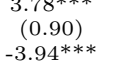 & 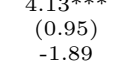 & 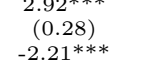 & 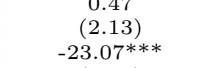 & 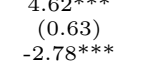 & 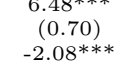 & 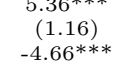 & 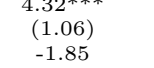 & 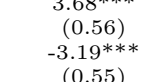 \\
\hline Concentration ratio & $\begin{array}{l}(6.24) \\
10.68\end{array}$ & 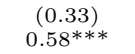 & $\begin{array}{l}(0.67) \\
0.05\end{array}$ & 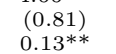 & $\begin{array}{l}(1.91) \\
0.20\end{array}$ & $\begin{array}{l}(0.55) \\
0.15\end{array}$ & $\begin{array}{l}(0.80) \\
1.2 .1^{*}\end{array}$ & $\begin{array}{l}(0.30) \\
0.49 * * *\end{array}$ & $\begin{array}{l}(0.43) \\
-0.10\end{array}$ & (0.59) & $\begin{array}{l}(1.71) \\
0.19\end{array}$ & $\begin{array}{l}(0.27) \\
0.09\end{array}$ & $\begin{array}{l}(6.24) \\
10.08\end{array}$ & $\begin{array}{l}(0.33) \\
0.53^{* * * *}\end{array}$ & $\begin{array}{l}(0.67) \\
0.05\end{array}$ & $\begin{array}{l}(0.81) \\
0.013 * \star\end{array}$ & $\begin{array}{l}(1.91) \\
0.20\end{array}$ & \\
\hline Reserve period ratio & $\begin{array}{l}\left.9_{2.78}^{2.73}\right) \\
2.78\end{array}$ & 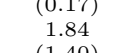 & $\left(\begin{array}{l}0.1 .104 \\
2.24 \\
a^{2}\end{array}\right.$ & $\begin{array}{c}(0.06) \\
-2.01 \\
-2.02\end{array}$ & $\begin{array}{l}\text { (2.48) } \\
\text { 2.48 } \\
2.40\end{array}$ & 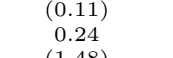 & 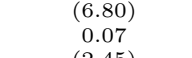 & $\begin{array}{l}(0.17) \\
0.57 \\
0.57\end{array}$ & 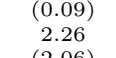 & $\begin{array}{l}(0.0 .66) \\
-2.80 \\
-2.80\end{array}$ & 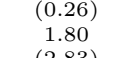 & 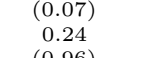 & 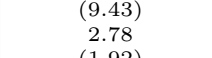 & $\begin{array}{l}(0.17) \\
1.84 \\
c .80\end{array}$ & $\begin{array}{l}\left(\begin{array}{l}0.104 \\
2.24\end{array}\right. \\
2.20\end{array}$ & 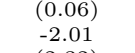 & $2.40^{\circ}$ & 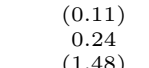 \\
\hline Dropped banks & & & & & & & & $\begin{array}{l}-1.27^{*} \\
0.65) \\
(0.65)\end{array}$ & 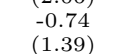 & 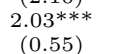 & $\begin{array}{l}\text { o.81 } \\
\text { o.1.17 }\end{array}$ & $\begin{array}{l}-0.59 \\
(0.42)\end{array}$ & & & & & & \\
\hline Constant & $\begin{array}{l}16.77 .7 * * \\
(4.30)\end{array}$ & $\begin{array}{l}-0.57 \\
(0.50)\end{array}$ & $\begin{array}{l}-1.87 * 7 * * \\
(0.70)\end{array}$ & $\begin{array}{l}-0.85 \\
(0.88)\end{array}$ & $\begin{array}{l}-3.0 .0 * * * * \\
(1.12)\end{array}$ & $\begin{array}{l}1.79 * * * * \\
(0.57)\end{array}$ & $\begin{array}{l}1.8 .97 * \\
0.77)\end{array}$ & $\begin{array}{l}0.21 \\
0.36)\end{array}$ & $\begin{array}{l}1.3 .0 * * \\
0.51)\end{array}$ & $\begin{array}{l}-0.67 \\
(0.60)\end{array}$ & $\begin{array}{l}-2.84 * * * * \\
(1.06)\end{array}$ & $\begin{array}{l}1.01+* * * \\
(0.28)\end{array}$ & 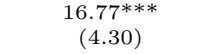 & $\begin{array}{l}-0.57 \\
(0.50)\end{array}$ & 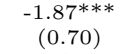 & $\begin{array}{l}-0.055 \\
(0.68)\end{array}$ & $\begin{array}{l}-3.00 * * * \\
(1.12)\end{array}$ & ;7) \\
\hline 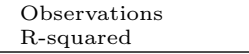 & 0.49 & $\begin{array}{l}1,182.21 \\
\end{array}$ & $\begin{array}{l}27.42 \\
0.42 \\
\end{array}$ & $\begin{array}{l}207 \\
0.24 \\
\mathrm{n}\end{array}$ & $\begin{array}{l}155 \\
0.10 \\
0\end{array}$ & $\begin{array}{l}343 \\
0.22 \\
\end{array}$ & $\begin{array}{l}321 \\
0.14 \\
\end{array}$ & $\begin{array}{l}1,678 \\
0.19 \\
\end{array}$ & $\begin{array}{l}432 \\
0.27 \\
0.25\end{array}$ & $\begin{array}{l}278 \\
0.24 \\
\end{array}$ & $\begin{array}{l}10.11 \\
0.11 \\
\end{array}$ & $\begin{array}{l}1,372 \\
0.15 \\
\end{array}$ & $\begin{array}{l}32 \\
0.49 \\
\end{array}$ & $\begin{array}{l}1,281 \\
0.22 \\
\end{array}$ & $\begin{array}{l}278 \\
0.42 \\
\end{array}$ & $\begin{array}{l}207 \\
0.24 \\
\end{array}$ & 0.10 & \\
\hline
\end{tabular}


Table 7: Pooled OLS results for am/pm volume imbalance for borrowers.

\begin{tabular}{|c|c|c|c|c|c|c|c|c|c|c|c|c|c|c|c|c|}
\hline & \multicolumn{4}{|c|}{\begin{tabular}{|l} 
Baseline regressions \\
All transactions
\end{tabular}} & \multicolumn{4}{|c|}{$\frac{\text { Min transaction } 25}{\text { Prectisis }}$} & \multicolumn{4}{|c|}{$\begin{array}{l}\text { Robusustness check } \\
\text { Moin transaction } 50 \\
\end{array}$} & \multicolumn{4}{|c|}{$\begin{array}{l}\text { Doroped banks controlled } \\
\text { Proper }\end{array}$} \\
\hline$\frac{\text { Variable }}{\text { Small banks }}$ & $\frac{\text { All }}{0.34}$ & 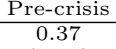 & $\frac{\text { Crisis }}{0.38}$ & $\begin{array}{l}\text { Post-crisis } \\
0.28^{* * *}\end{array}$ & $\frac{\mathrm{All}}{0.36}$ & $\begin{array}{ll}\text { Pre-crisis } \\
0.40\end{array}$ & $\begin{array}{c}\text { Cliris } \\
0.39\end{array}$ & ost-crisis & 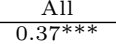 & 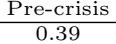 & & 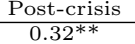 & $\frac{\text { All }}{0.35}$ & $\begin{array}{l}\text { Precciris } \\
\text { o.36 }\end{array}$ & $\frac{c_{13 i s i}}{0.38}$ & 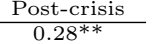 \\
\hline Medium banks & $\begin{array}{l}(0.05) \\
0.26^{* *}\end{array}$ & (c.024) & (0.07) & $\left(\begin{array}{l}0.08) \\
0.34\end{array}\right.$ & 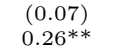 & $\left(\begin{array}{l}0.12) \\
0.26\end{array}\right.$ & $\left(\begin{array}{c}0.122 \\
0.24\end{array}\right.$ & (0.12) & $\begin{array}{llll}(0.10) \\
0.40^{* * * *}\end{array}$ & $\begin{array}{l}(0.07) \\
0.49^{*}\end{array}$ & $\begin{array}{l}(0.16) \\
0.49 * * *\end{array}$ & $\begin{array}{l}(0.16) \\
0.40^{* *}\end{array}$ & $\begin{array}{l}(0.05) \\
0.02 *\end{array}$ & 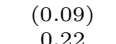 & $\left(\begin{array}{c}0.072 \\
0.27\end{array}\right)$ & 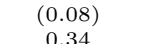 \\
\hline Large banks & $(0.05)$ & (0.10) & (0.08) & (0.09) & $\begin{array}{l}(0.08) \\
(0.08 *\end{array}$ & 罂.13) & $(0.13)$ & (0.13) & $\left.\begin{array}{l}(0.10) \\
(0,10 * x\end{array}\right)$ & (0.08) & $\begin{array}{l}(0.16) \\
(0.16)\end{array}$ & 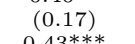 & $\left(\begin{array}{l}0.05) \\
(0.0)\end{array}\right.$ & $(0.10)$ & (0.08) & $(0.09)$ \\
\hline Lalge danks & $\begin{array}{l}.0 .05 \\
0.05 \\
0.2 x\end{array}$ & $\begin{array}{l}0.18 \\
0.10 * \\
(0.2\end{array}$ & $\begin{array}{l}0.28 \\
0.08 \\
0.024 x\end{array}$ & 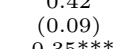 & 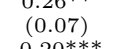 & $\begin{array}{ll}0.10 \\
(0.14)\end{array}$ & 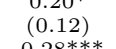 & 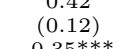 & (0.10) & 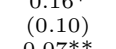 & $\begin{array}{l}0.216) \\
(0.167\end{array}$ & $\begin{array}{l}0.4377) \\
(0.17 *)\end{array}$ & $\begin{array}{l}0.205 \\
0.05\end{array}$ & $\begin{array}{l}0.140 \\
0.10 \% \\
0.12 x\end{array}$ & $\begin{array}{l}0.23 \\
0.08 x^{2}\end{array}$ & $\begin{array}{l}0.42) \\
(0.09 * * *\end{array}$ \\
\hline Foreign banks & $\begin{array}{c}(0.06) \\
-0.06 * * *\end{array}$ & 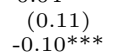 & 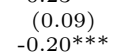 & 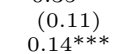 & 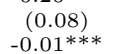 & 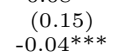 & 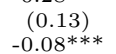 & 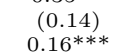 & $\left(\begin{array}{c}0.11) \\
0.08\end{array}\right.$ & $\begin{array}{l}(0.11) \\
0.03 * * *\end{array}$ & $\begin{array}{l}(0.17) \\
0.00 * * *\end{array}$ & (0.18) & 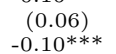 & 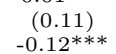 & $\begin{array}{c}(0.09) \\
-0.211^{2 * * *}\end{array}$ & $\begin{array}{l}(0.11) \\
0.1 *^{* * *}\end{array}$ \\
\hline Dropped banks & $(0.05)$ & $(0.09)$ & $(0.07)$ & $(0.09)$ & $(0.07)$ & (0.13) & $(0.12)$ & $(0.13)$ & $(0.10)$ & $(0.09)$ & (0.16) & (0.18) & $\begin{array}{l}(0.05) \\
0.03\end{array}$ & $\begin{array}{l}(0.09) \\
0.100^{* *}\end{array}$ & $\stackrel{(0.07)}{0.03}_{0.07}$ & (0.09) \\
\hline Constant (Minor ref. group) & $0.37 * 0 * *$ & $0.33^{* * *}$ & $0.34 * * *$ & $\begin{array}{l}0.4 * * * * \\
0.077)\end{array}$ & $\begin{array}{l}0.45^{* * *} \\
0.07\end{array}$ & $0.43 * * *$ & $0.44^{* * * *}$ & $0.50 * * *$ & $\begin{array}{l}-0.06 \\
(0.10)\end{array}$ & $\begin{array}{l}0.33^{* * *} \\
0.0707\end{array}$ & $0.44 * * *$ & -0.04 & 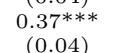 & $\begin{array}{c}0.317+* x \\
0.090\end{array}$ & 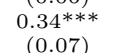 & $\left.\begin{array}{c}0.44 * * * \\
0.07\end{array}\right)$ \\
\hline$\underset{\substack{\text { Observations } \\
\text { R-sounard }}}{ }$ & 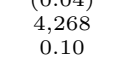 & $\begin{array}{l}1,438 \\
0.110\end{array}$ & 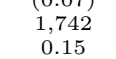 & $\begin{array}{l}1,088 \\
0.05\end{array}$ & 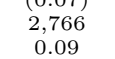 & $\begin{array}{l}825 \\
0.10\end{array}$ & $\begin{array}{l}0,110 \\
0.11\end{array}$ & $\begin{array}{l}831 \\
0.07\end{array}$ & 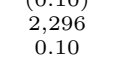 & $\begin{array}{l}673 \\
0.09\end{array}$ & $\begin{array}{l}010 \\
9118 \\
0.18\end{array}$ & $\begin{array}{l}713 \\
71.09\end{array}$ & 年, 4.268 & $\begin{array}{l}1,438 \\
0.10\end{array}$ & 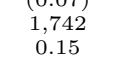 & $\begin{array}{l}0,088 \\
0.05\end{array}$ \\
\hline
\end{tabular}

Table 8: Pooled OLS results for quoter/aggressor volume imbalance for borrowers.

\begin{tabular}{|c|c|c|c|c|c|c|c|c|c|c|c|c|c|c|c|c|}
\hline \multirow{10}{*}{$\begin{array}{l}\text { Variable } \\
\text { Small banks } \\
\text { Medium banks } \\
\text { Large banks } \\
\text { Major banks } \\
\text { Foreign banks } \\
\text { Dropped banks } \\
\text { Constant (Minor ref. group) } \\
\text { Osbervations } \\
\text { R-squared }\end{array}$} & \multirow{2}{*}{\multicolumn{4}{|c|}{$\begin{array}{l}\text { Baseline regressions } \\
\text { Allt transactions }\end{array}$}} & \multicolumn{12}{|c|}{$\begin{array}{l}\text { Robustness check } \\
\text { Min transaction } \\
\text { Mi }\end{array}$} \\
\hline & $\frac{A \| 1}{0.23^{3 * * *}}$ & & & $\begin{array}{l}\text { Post-crisis } \\
0 \text { O4tox }\end{array}$ & $\frac{\text { All }}{0.33^{*}}$ & 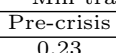 & 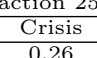 & $\begin{array}{l}\text { Post-crisis } \\
\text { Potis }\end{array}$ & $\frac{A l}{0.37 * *}$ & 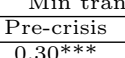 & & 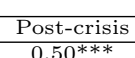 & 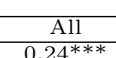 & 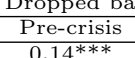 & 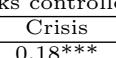 & $\begin{array}{l}\text { Post-crisis } \\
\text { Pot- } * * * *\end{array}$ \\
\hline & 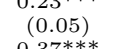 & $\begin{array}{l}0.10) \\
(0.10 * * * \\
0.70\end{array}$ & $\begin{array}{l}0.197) \\
(0.07)\end{array}$ & $\begin{array}{l}0.408) \\
0.08 .2 \\
0.04\end{array}$ & $\begin{array}{l}.3 .09) \\
(0.09 *\end{array}$ & $\begin{array}{l}(.28) \\
(0.187\end{array}$ & $\begin{array}{l}0.20 \\
(0.12)\end{array}$ & (0.15) & 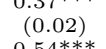 & $\begin{array}{l}0.30 .03) \\
(0.03 * *\end{array}$ & 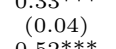 & $\begin{array}{l}0.0 .03) \\
(0.03 * x\end{array}$ & $\begin{array}{l}0.245) \\
(0.05)\end{array}$ & 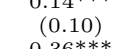 & $\begin{array}{l}0.187) \\
(0.077 .2\end{array}$ & $\begin{array}{l}0.408) \\
0.08 * * * \\
0.02 *\end{array}$ \\
\hline & 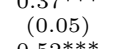 & $\begin{array}{l}0.350 .11 \\
0.11 \\
0.1 .2 \times\end{array}$ & 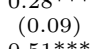 & $\begin{array}{l}0.3510) \\
0.10 .2\end{array}$ & $\begin{array}{l}.0 .049 \\
(0.09 * * *\end{array}$ & $\begin{array}{l}0.31^{*} \\
(0.19)\end{array}$ & $\left.\begin{array}{l}0.23 \\
(0.13) \\
0.7 * * *\end{array}\right)$ & 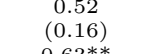 & 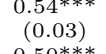 & 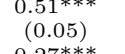 & 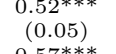 & 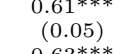 & $\begin{array}{l}0.40 .74 \\
(0.05) \\
0.05 x\end{array}$ & 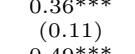 & 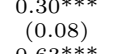 & $\begin{array}{l}0.53 .10 * \\
0.10 * * * \\
0.10 *\end{array}$ \\
\hline & $(0.05)$ & $(0.10)$ & $(0.08)$ & $(0.09)$ & (0.090 & $(0.20)$ & 0 & 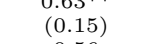 & $(0.04)$ & $(0.08$ & $(0.05)$ & (0.004) & $(0.05)$ & (0.11) & (0.0.0) & (jo.099) \\
\hline & 0.060 & (0.0.11) & 0 & 0.0 .012 & $\begin{array}{l}0.53 \\
0.09\end{array}$ & 0 & 0 & $\begin{array}{l}0.56 \\
0.177\end{array}$ & 0 & $\begin{array}{l}0.38 \\
0.07\end{array}$ & (0.0.0.07) & 0.090 & 0.067 & 0.0911 & 0.609 & 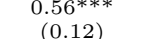 \\
\hline & 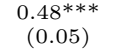 & $\begin{array}{l}0.46 * * * * \\
0.10)\end{array}$ & $\begin{array}{l}0.47 * * * \\
(0.07)\end{array}$ & $\begin{array}{l}0.56 \sigma^{* * * *} \\
(0.09)\end{array}$ & $\begin{array}{l}0.59 * * * \\
(0.09)\end{array}$ & $\begin{array}{l}0.48+* * * \\
(0.19)\end{array}$ & $\begin{array}{l}0.60 * * * \\
(0.12)\end{array}$ & $\begin{array}{l}0.68 * 8 \\
0.15)\end{array}$ & $\begin{array}{l}0.56 * * * \\
(0.04)\end{array}$ & $\begin{array}{l}0.40 * * * \\
(0.07)\end{array}$ & $\begin{array}{l}0.600 * * * \\
(0.06) \\
(0.06)\end{array}$ & $\begin{array}{l}0.68 * 0 * * \\
(0.06)\end{array}$ & $\begin{array}{l}0.54 * 2 * x \\
0.05)\end{array}$ & $\begin{array}{l}0.49 * * * * \\
(0.0)\end{array}$ & 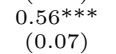 & $\begin{array}{l}0.56 \% * * * \\
(0.09)\end{array}$ \\
\hline & & & & & & & & & & & & & $\begin{array}{l}-0.2 .94) \\
(0.04)\end{array}$ & 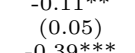 & $\begin{array}{l}-\frac{0.486}{(0.06)} \\
(0.66)\end{array}$ & \\
\hline & 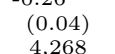 & $\begin{array}{l}0.4109) \\
(0.098\end{array}$ & $\begin{array}{l}0 \\
-0.07) \\
(0.72)\end{array}$ & $\begin{array}{l}-0.08) \\
0.088 \\
0.088\end{array}$ & $\begin{array}{l}(0.08) \\
(0.766\end{array}$ & $\begin{array}{l}-0.18 \\
0.185 \\
0.225\end{array}$ & $\begin{array}{l}\text { (1.12) } \\
\text { (1.110 }\end{array}$ & $\begin{array}{l}0.14) \\
0.014) \\
0.021\end{array}$ & 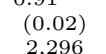 & 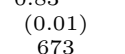 & $\begin{array}{l}0.04) \\
(0.04) \\
010\end{array}$ & 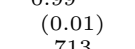 & $\begin{array}{l}-6.04) \\
\text { (0.0.04) } \\
4.268\end{array}$ & 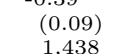 & $\begin{array}{l}-0.07 \\
0.07 \\
0.72 \\
0.72\end{array}$ & $\begin{array}{l}-\frac{0.08}{0.089} \\
1.088\end{array}$ \\
\hline & & & 0.099 & & & 0.032 & & & & 0.027 & 0.069 & & 0.101 & 0.107 & 0.139 & 0.077 \\
\hline
\end{tabular}

Table 9: Pooled OLS results for lenders.

\begin{tabular}{|c|c|c|c|c|c|c|c|c|c|c|c|c|c|c|c|c|}
\hline \multirow[b]{2}{*}{$\begin{array}{c}\mathrm{m} \text { in } \\
\end{array}$} & \multicolumn{4}{|c|}{ action } & & & \\
\hline & & & & & & & & & & & & & & & & \\
\hline balance ratio & & & & & & & & & & & & & & & & \\
\hline & & & $\begin{array}{l}2.1877) \\
(0.47)\end{array}$ & $\begin{array}{l}4.1 .56) \\
0.566 *\end{array}$ & (0.25) & & & & $0.27 x$ & (jo. & $\begin{array}{l}2.9 .91 \\
(0.31)\end{array}$ & $\begin{array}{l}2.593 .72 \\
0.72\end{array}$ & (0.28) & & & 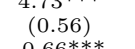 \\
\hline & & & .11) & & & & & & & & . & & & & & (0.15) \\
\hline $\mathrm{cos}$ & $(0.83)$ & 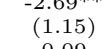 & (1.61) & $\begin{array}{l}-1.05 \\
(1.05 *\end{array}$ & (1.07) & 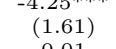 & 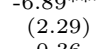 & $\begin{array}{l}-0.0 \\
\text { (1. }\end{array}$ & (1.1.19) & 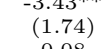 & $(2.4$ & $\begin{array}{l}-0 \\
(1) \\
7\end{array}$ & $(4)$ & & 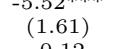 & $\begin{array}{l}-1.37 \\
(1.05)\end{array}$ \\
\hline & & & & $\begin{array}{l}\frac{1.4 .1}{(0.6} \\
(.6)\end{array}$ & & & & & & & & & & & & 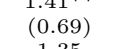 \\
\hline um Dar & 444) & $\begin{array}{l}-0.06 \\
(0.46) \\
(0.06\end{array}$ & $\begin{array}{l}0.08 \\
(0.75)\end{array}$ & $\begin{array}{l}1.38 \\
0.96\end{array}$ & 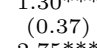 & $\begin{array}{l}0 \\
(c \\
(c)\end{array}$ & $\begin{array}{l}1.0 .0 x^{*} \\
(0.58)\end{array}$ & $(0.90)$ & $(0.36)$ & $(0.16)$ & $(0.51)$ & $\begin{array}{l}1.1 \\
0 .\end{array}$ & $(0.44)$ & (0. & $(0.76$ & $\begin{array}{l}\begin{array}{l}1.35 \\
(0.90)\end{array} \\
\text {. }\end{array}$ \\
\hline M. & & $(0.2)$ & ${ }_{0}^{0}$ & 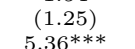 & 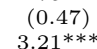 & (c) & $\begin{array}{l}0.7 \\
1.9\end{array}$ & $\begin{array}{l}(1 .) \\
6.98\end{array}$ & $\begin{array}{l}0.4 \\
3.10 \\
3.10\end{array}$ & (c) & (0. & $\begin{array}{c}(1) \\
6.9\end{array}$ & $\begin{array}{l}C_{2} \\
23\end{array}$ & & 1 & $\begin{array}{l}(1.1 \\
{ }_{5}^{1.36}\end{array}$ \\
\hline Foreign banks & $\begin{array}{l}{ }_{0}^{\prime} \\
0 .\end{array}$ & 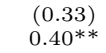 & $\begin{array}{l}(1.03 \\
0.69\end{array}$ & $\begin{array}{l}(1.40) \\
1.33\end{array}$ & $\begin{array}{l}(0.64 \\
1.94^{*}\end{array}$ & $l_{0.16}^{(0.32)}$ & $\begin{array}{r}(1.13) \\
2.00^{* * *}\end{array}$ & $\begin{array}{l}(1.1 .77 \\
3.67^{* *}\end{array}$ & 2 & ${ }_{0 .}^{(0 .}$ & $\begin{array}{c}(1.14) \\
1.55^{* * *}\end{array}$ & $\begin{array}{l}(1.38 \\
4.10^{*}\end{array}$ & $\begin{array}{l}0.5 \\
0.90 \\
0\end{array}$ & $\begin{array}{c}(0 . \\
0.4\end{array}$ & 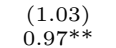 & $\stackrel{(1.40)}{1.33}_{1.33}$ \\
\hline ed banks & & (c & & & $(0.4$ & $(0.26)$ & .54) & $(1.02)$ & 0.4 & $(0.17)$ & $(0.64)$ & $(1.27)$ & & & $(0.4)$ & $(0.92)$ \\
\hline Constar & 1.:59*3 & $(0.4)$ & 2.28 & & & & & & & & & & & & & \\
\hline atistics & & & & & & & & & & & & & & & & $\begin{array}{l}1,452 \\
0.16 \\
423\end{array}$ \\
\hline
\end{tabular}

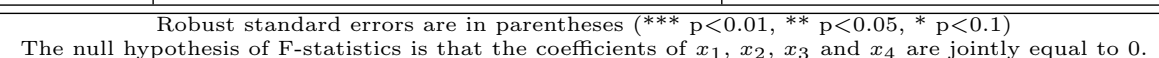


Table 10: Fixed-effect model results for lenders.

\begin{tabular}{|c|c|c|c|c|c|c|c|c|c|c|c|c|c|c|c|c|}
\hline \multirow{7}{*}{$\begin{array}{l}\text { Variable } \\
\text { Ammpm imbalance } \mathrm{r} . \\
\text { Q/a imbalance ratio } \\
\text { Concentation aatio } \\
\text { Reserve period ratio } \\
\text { Observations } \\
\text { R-s-suared } \\
\text { Number of lenders }\end{array}$} & \multirow{2}{*}{\multicolumn{4}{|c|}{$\begin{array}{l}\text { All transactions } \\
\text { foccisis }\end{array}$}} & \multirow{2}{*}{\multicolumn{4}{|c|}{$\begin{array}{l}\text { Min transaction } 25 \\
\text { reccivis }\end{array}$}} & \multirow{2}{*}{\multicolumn{4}{|c|}{ Min transaction 50}} & \multirow{2}{*}{\multicolumn{4}{|c|}{$\begin{array}{l}\text { Dropped banks controlled } \\
\text { Crisisectisis }\end{array}$}} \\
\hline & & & & & & & & & & & & & & & & \\
\hline & & & & & & & & & & & & & & $1.099^{* *}$ & & \\
\hline & $\begin{array}{l}2.313 * * * * \\
(0.463)\end{array}$ & $\begin{array}{l}1.706 * * \\
(0.081)\end{array}$ & $\begin{array}{l}3.431 * * * \\
(0.699)\end{array}$ & $\begin{array}{l}2.8 .16 * * \\
(1.130)\end{array}$ & $\begin{array}{l}2.5448 * * * \\
(0.602)\end{array}$ & $\begin{array}{l}2.409 * * * * \\
(0.890)\end{array}$ & $(0.8)$ & & $(0.588)$ & $(0.720)$ & $(0.6)$ & (1. & $(0.463)$ & $(0.6)$ & $(0.6)$ & (1.1.130 \\
\hline & $\begin{array}{l}-3.599 * * * \\
-(0.810) \\
(0.0)\end{array}$ & 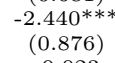 & $\left.\begin{array}{l}-4.7 .21+* * \\
(1.442)\end{array}\right)$ & $\begin{array}{l}-2.117 \\
(1.325) \\
(1.35)\end{array}$ & 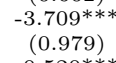 & $\begin{array}{l}-3.44 .43 * * * \\
(1.554) \\
(1.54)\end{array}$ & $(1.784)$ & $\begin{array}{l}-2.264 \\
(1.491) \\
(1.49)\end{array}$ & 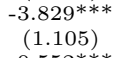 & $(1$. & $(1.98)$ & $\begin{array}{l}-2.240 \\
(1.680) \\
(1.680\end{array}$ & $(0$ & $\begin{array}{l}2.440 * * \\
(0.876)\end{array}$ & ${ }^{(1}$ & $(1.32$ \\
\hline & & & & & & & & & & & & & & & & \\
\hline & $\begin{array}{l}5,115 \\
0.115 \\
0.95\end{array}$ & $\begin{array}{l}1,106 \\
0.108 \\
0.108\end{array}$ & 18 & 0.13 & $\begin{array}{l}4.0,38 \\
0.100 \\
\text { 104 }\end{array}$ & 104 & $\begin{array}{l}1,598 \\
0.163 \\
0.164\end{array}$ & & $\begin{array}{l}0.1147 \\
.88\end{array}$ & 0.1850 & & . & $\begin{array}{c}5,5,58 \\
0.15 \\
0.15\end{array}$ & & 181 & $\begin{array}{l}\text { b.1.137 } \\
.157\end{array}$ \\
\hline
\end{tabular}

Table 11: Pooled OLS results for different groups of lenders.

\begin{tabular}{|c|c|c|c|c|c|c|c|c|c|c|c|c|c|c|c|c|c|c|}
\hline & All minor bai & 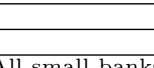 & $\begin{array}{l}\text { Base } \\
\text { All } \\
\text { Al }\end{array}$ & $\begin{array}{l}\text { regrestions } \\
\text { escetions }\end{array}$ & & & & & 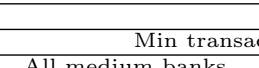 & & & & & & 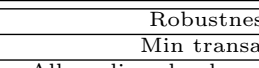 & $\begin{array}{l}\text { secteck } \\
\text { sction } 50 \\
\text { ction }\end{array}$ & & \\
\hline $\begin{array}{l}\text { Variable } \\
\mathrm{Am} / \mathrm{mm} \text { imbalance }\end{array}$ & $\begin{array}{l}\text { All minor banks } \\
2.87^{* * *}\end{array}$ & $\begin{array}{l}\text { Ill small bank } \\
4.46^{* * * *}\end{array}$ & $\begin{array}{l}\text { All medium be } \\
5.00^{* * * *}\end{array}$ & $\begin{array}{l}\text { All large banks } \\
3.87^{* * *}\end{array}$ & $\begin{array}{l}\text { All major banks } \\
3.55^{* * *}\end{array}$ & $\begin{array}{l}5 \text { All foreieng banks } \\
2.19^{* * *}\end{array}$ & $\begin{array}{l}\text { All minor banks } \\
3.22^{* * *}\end{array}$ & $\begin{array}{l}\text { All small bank } \\
4.35^{* * * *}\end{array}$ & 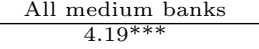 & $\begin{array}{l}\text { large banks } \\
\text { 3.78* }\end{array}$ & $\begin{array}{l}\text { All major banks } \\
3.59^{* * *}\end{array}$ & $\begin{array}{l}\text { All foreign banks } \\
2.77^{* * * *}\end{array}$ & \begin{tabular}{|l|} 
All minor banks \\
$3.22^{* * *}$
\end{tabular} & $\begin{array}{c}\text { All small banks } \\
33.99^{* * *}\end{array}$ & $\begin{array}{l}\text { All medium banks } \\
4.22^{* * * *}\end{array}$ & $\begin{array}{l}11 \text { large banks } \\
3.77^{* * *}\end{array}$ & 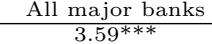 & 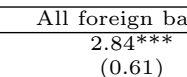 \\
\hline Q/a imbalance ratio & $\begin{array}{l}(0.42) \\
3.94 * * *\end{array}$ & 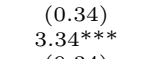 & $\begin{array}{l}(0.78) \\
2.14 * * *\end{array}$ & 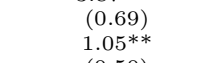 & $\begin{array}{l}0.97) \\
2.54 * * * \\
2.54\end{array}$ & $\left.\begin{array}{l}(0.33) \\
1.17\end{array}\right)$ & $\begin{array}{l}0.0 .47) \\
3.68 * * *\end{array}$ & 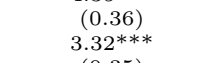 & 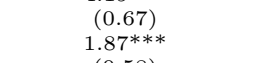 & $\begin{array}{l}(0.85) \\
1.84 *\end{array}$ & $\begin{array}{l}(1.01) \\
2.56^{* * * *}\end{array}$ & $\begin{array}{l}(0.46) \\
2.08 * * \\
\text { (a) }\end{array}$ & $\begin{array}{c}0.477 \\
3.68 * * * \\
3\end{array}$ & $\begin{array}{l}(0.37) \\
3.42 * * * \\
3\end{array}$ & $\begin{array}{l}(0.72) \\
1.99 * * \\
\end{array}$ & $\begin{array}{l}(0.85) \\
1.84^{*}\end{array}$ & $\begin{array}{l}(1.01) \\
2.56^{* * *}\end{array}$ & $\begin{array}{l}(0.61) \\
2.80 \\
(1.72)\end{array}$ \\
\hline Concentration ratio & $\begin{aligned} & (0.45) \\
-1.90 * * * & \end{aligned}$ & $\begin{array}{l}\text { (0.34) } \\
-0.76^{* * *}\end{array}$ & $\begin{array}{l}(0.78) \\
-0.66^{* * *}\end{array}$ & $\begin{array}{l}(0.50) \\
-0.16\end{array}$ & ${ }_{-0.84^{*}}^{(0.82)}$ & $\left(\begin{array}{l}0.75) \\
0.05\end{array}\right.$ & $\begin{array}{l}(0.36) \\
-1.72 * *\end{array}$ & $\begin{array}{l}(0.35) \\
-0.73 * *\end{array}$ & $\begin{array}{l}(0.58) \\
-0.77 * * *\end{array}$ & $\overbrace{-0.10}^{0.933}$ & $\begin{array}{l}(0.9 .91) \\
-0.31\end{array}$ & $\begin{array}{l}(0.90) \\
-0.06\end{array}$ & 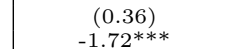 & 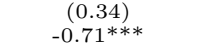 & $\begin{array}{l}(0.61) \\
-0.60^{* *}\end{array}$ & $\begin{array}{l}(0.9 .93) \\
-0.10\end{array}$ & 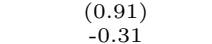 & $\begin{array}{l}(1.72) \\
-0.10 \\
-0.12\end{array}$ \\
\hline Reserve period ratio & $\begin{array}{l}\left(\begin{array}{l}0.35) \\
-4.56 * \\
(2.18)\end{array}\right. \\
(2.18)\end{array}$ & 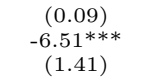 & $\begin{array}{l}(0.22) \\
-6.29 * * \\
(3.15) \\
(3.15)\end{array}$ & $\begin{array}{l}\left(\begin{array}{c}0.15) \\
-0.80 \\
(1.67)\end{array}\right. \\
(1.67\end{array}$ & 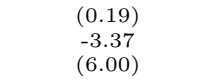 & $\begin{array}{l}(0.10) \\
0.55 \\
(1.16)\end{array}$ & $\begin{array}{l}(0.30) \\
-2.12 \\
(2.09)\end{array}$ & 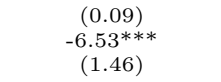 & $\begin{array}{l}(0.25) \\
-1.26 \\
(1.42)\end{array}$ & 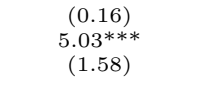 & $\begin{array}{l}(0.21) \\
\left(\begin{array}{l}2.02 \\
(6.62)\end{array}\right.\end{array}$ & 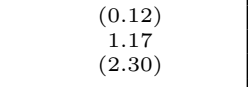 & $\begin{array}{l}(0.30) \\
-2.12 \\
(2.09)\end{array}$ & 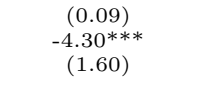 & 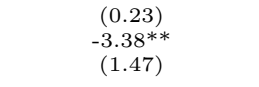 & $\begin{array}{l}\substack{0.16 .16) \\
5.03 * * * \\
(1.58)} \\
(1.5)\end{array}$ & $\begin{array}{l}(0.21) \\
-2.202 \\
(6.62)\end{array}$ & $\begin{array}{l}\left(\begin{array}{l}0.14) \\
1.43 \\
(3.38)\end{array}\right. \\
\end{array}$ \\
\hline Constant & $3.42^{* * * *}$ & $3.02^{* * *}$ & $2.45^{5 * * *}$ & $1.12^{* * *}$ & $3.64 * * *$ & -0.01 & $2.20^{* * * *}$ & $2.95^{* * *}$ & $1.54^{* * *}$ & 0.79 & $3.52^{* * * *}$ & 0.97 & $2.22^{* * * *}$ & $2.78^{* * * *}$ & $1.47^{* * * *}$ & 0.79 & 3.52*** & \\
\hline $\begin{array}{l}\text { Observations } \\
\text { Resurad }\end{array}$ & 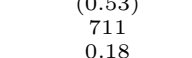 & $\begin{array}{l}0.236 \\
2.226 \\
0.19\end{array}$ & 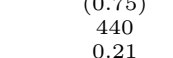 & 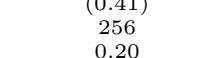 & $\begin{array}{l}(1.117) \\
197 \\
012\end{array}$ & $\begin{array}{l}0.738 \\
100 \\
0.05\end{array}$ & 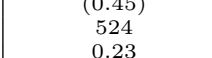 & $\begin{array}{l}0.104 \\
2,104 \\
018\end{array}$ & 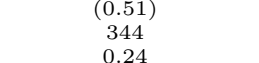 & $\begin{array}{l}\left(\begin{array}{l}0.800 \\
116 \\
027\end{array}\right. \\
027\end{array}$ & $\begin{array}{c}\left(\begin{array}{c}1.30) \\
165 \\
01\end{array}\right. \\
010\end{array}$ & $\begin{array}{l}\left(\begin{array}{c}0.999 \\
75 \\
008\end{array}\right. \\
0.0\end{array}$ & 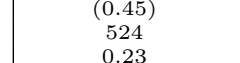 & $\begin{array}{l}0.0 .34) \\
1,961 \\
016\end{array}$ & 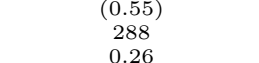 & 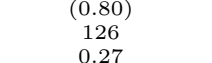 & 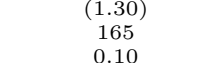 & $\begin{array}{l}439 \\
0.08\end{array}$ \\
\hline
\end{tabular}

Table 12: Pooled OLS results for am/pm volume imbalance ratio for lenders.

\begin{tabular}{|c|c|c|c|c|c|c|c|c|c|c|c|c|c|c|c|c|}
\hline $\begin{array}{l}\text { Variable } \\
\end{array}$ & \multicolumn{4}{|c|}{$\begin{array}{l}\text { Baseline regressions } \\
\text { Arll transactions } \\
\text { Precrisis } \\
\text { Crisis }\end{array}$} & \multicolumn{4}{|c|}{$\begin{array}{l}\frac{\text { Min transaction } 25}{\text { Pre-crisis }} \text { Crisis } \\
\text { Pris }\end{array}$} & \multicolumn{4}{|c|}{ 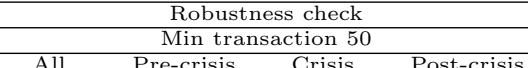 } & \multicolumn{4}{|c|}{$\begin{array}{l}\text { Dropped banks controlled } \\
\text { Pre-crisis } \\
\text { Prisis }\end{array}$} \\
\hline Small banks & 0.13 & & & & $0.18^{* * * *}$ & $0.12^{* * * *}$ & $0.14^{* * *}$ & 0.31 & $0.21^{* *}$ & $0.16^{* *}$ & $0.16^{* * *}$ & 0.35 & & & & \\
\hline Medium banks & 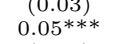 & $\begin{array}{l}(0.05) \\
-0.04^{* * *}\end{array}$ & 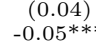 & $\left(\begin{array}{l}0.04) \\
0.28\end{array}\right.$ & 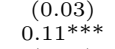 & $\begin{array}{l}0.0 .05 * \\
0.04 * 27\end{array}$ & $\begin{array}{l}(0.0 .0 \\
0.03\end{array}$ & $\begin{array}{l}(0.05) \\
0.31\end{array}$ & $\begin{array}{c}(0.03) \\
0.18 * * *\end{array}$ & $\begin{array}{l}0.0 .05 \\
0.08 * 2\end{array}$ & $\begin{array}{l}0.0 .04 \pi \\
0.10^{2} \neq *\end{array}$ & $\left(\begin{array}{l}0.05) \\
0.37\end{array}\right.$ & $\begin{array}{l}(0.03) \\
0.05^{*} * *\end{array}$ & 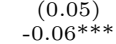 & $\begin{array}{l}-0.0 .05 \\
-0.5\end{array}$ & $\begin{array}{l}(0.04) \\
0.28\end{array}$ \\
\hline Large banks & $\begin{array}{l}0.0 .20 \\
0.20 \\
0.20\end{array}$ & $\begin{array}{l}0.074^{*} \\
0.37\end{array}$ & $\begin{array}{l}(0.06) \\
0.13 \\
0.13\end{array}$ & $\begin{array}{l}0.0 .07 * x \\
0.01+x\end{array}$ & $\underbrace{(0.04)}_{0.29}$ & 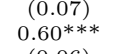 & 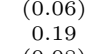 & 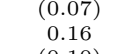 & $\begin{array}{l}(0.04) \\
0.29 \\
2\end{array}$ & 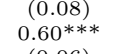 & 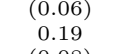 & 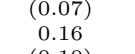 & 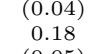 & $\begin{array}{l}(0.07) \\
0.28\end{array}$ & 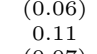 & $\begin{array}{l}(0.07) * \\
0.01 * * *\end{array}$ \\
\hline Major banks & 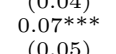 & 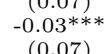 & $\begin{array}{lll}-0.01 * * \\
-0.077 \\
0.07\end{array}$ & $\begin{array}{l}0.28 \\
0.28 \\
0.102\end{array}$ & 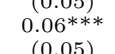 & 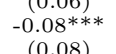 & $\begin{array}{l}0.00 * * * \\
0.007 \\
(0.07)\end{array}$ & (2.28 & 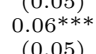 & 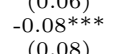 & 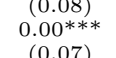 & 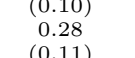 & $\left.\begin{array}{l}0.0 .05 * \\
0.06 * * * \\
0.05\end{array}\right)$ & 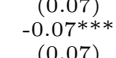 & $\begin{array}{c}-0.07 * * \\
-0.02 * * \\
0.07)^{2}\end{array}$ & $\begin{array}{l}(1.10) \\
0.28 \\
(2.10)\end{array}$ \\
\hline Foreign banks & 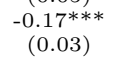 & 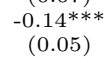 & $\begin{array}{l}-0.24 * * \\
(0.04) \\
(0.04)\end{array}$ & 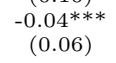 & 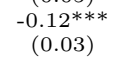 & 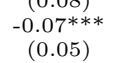 & 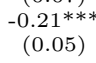 & 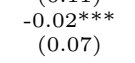 & $\begin{array}{l}0.04 * * * * \\
(0.04)\end{array}$ & 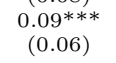 & 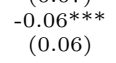 & $\begin{array}{l}0.16^{*} \\
(0.08)\end{array}$ & 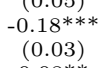 & 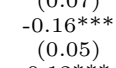 & $\begin{array}{l}-0.26^{* *+4} \\
(0.04)\end{array}$ & $\begin{array}{l}0.04 * * * * \\
0.066)\end{array}$ \\
\hline Dropped banks & & & & & & & & & & & & & $(0$. & $\begin{array}{l}0.1204) \\
(0.04 * * 2\end{array}$ & & \\
\hline Constant (Minor ref. group) & 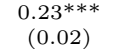 & $\begin{array}{l}0.22^{* * * *} \\
(0.04)\end{array}$ & ${ }_{(0.04)}^{(10.04)}$ & 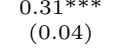 & 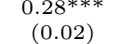 & $\begin{array}{l}0.288 .04 \\
0.04\end{array}$ & $\begin{array}{c}0.28 * * * \\
(0.04)\end{array}$ & $\begin{array}{l}0.30 * * * \\
(0.04)\end{array}$ & $\begin{array}{l}0.28 * 2 * * \\
(0.02)\end{array}$ & 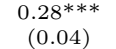 & 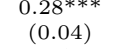 & $\begin{array}{l}0.0 .0 * 4 * \\
(0.04)\end{array}$ & (0.02) & $(0.04)$ & $\begin{array}{l}0.16 * * * * \\
(0.04)\end{array}$ & $\begin{array}{l}0.3 . * * * * \\
(0.04)\end{array}$ \\
\hline 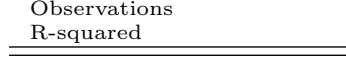 & $\begin{array}{l}5.568 \\
0.063 \\
0\end{array}$ & $\begin{array}{l}1,816 \\
0.056\end{array}$ & $\begin{array}{l}2,300 \\
0.074 \\
0.07\end{array}$ & $\begin{array}{l}1,452 \\
0.045 \\
0\end{array}$ & $\begin{array}{l}4,038 \\
0.047 \\
\end{array}$ & $\begin{array}{l}1,2.23 \\
0.053 \\
\end{array}$ & $\begin{array}{l}1,598 \\
0.073 \\
\end{array}$ & $\begin{array}{l}1,237 \\
0.035 \\
-10\end{array}$ & $\begin{array}{l}3,503 \\
0.017 \\
\end{array}$ & $\begin{array}{l}1,020 \\
0.038 \\
0\end{array}$ & $\begin{array}{l}1,372 \\
0.031 \\
\end{array}$ & $\begin{array}{l}1,111 \\
0.014 \\
\end{array}$ & $\begin{array}{l}5,5.58 \\
0.064 \\
\end{array}$ & $\begin{array}{l}1,816 \\
0.061 \\
\end{array}$ & $\begin{array}{l}2,300 \\
0.075 \\
\end{array}$ & $\begin{array}{l}.452 \\
.045 \\
\end{array}$ \\
\hline
\end{tabular}


Table 13: Pooled OLS results for quoter/aggressor volume imbalance for lenders.

\begin{tabular}{|c|c|c|c|c|c|c|c|c|c|c|c|c|c|c|c|c|}
\hline Variable & \multicolumn{4}{|c|}{$\begin{array}{c}\text { Baseline regressions } \\
\text { Allt transactions }\end{array}$} & \multicolumn{4}{|c|}{ Min transaction 25} & \multicolumn{4}{|c|}{$\begin{array}{l}\text { Robustness check } \\
\text { Min transaction } 50 \\
\end{array}$} & \multicolumn{4}{|c|}{$\begin{array}{l}\text { Dropped banks controlled } \\
\text { Preccerisis }\end{array}$} \\
\hline Small banks & & & $-0,57 * *$ & is & & & & & & & & & & & & \\
\hline Small banks & $\begin{array}{l}-0.09 .02) \\
(0.02)\end{array}$ & $\begin{array}{l}-0.05404) \\
(0.04)\end{array}$ & $\begin{array}{c}-0.5 .57 * \\
(0.03) \\
(0.7)\end{array}$ & $\begin{array}{l}-\frac{0.06 * *}{(0.04)} \\
(0.4)\end{array}$ & $\begin{array}{l}-0.5 .5 * * * \\
(0.02)\end{array}$ & 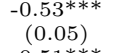 & 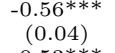 & (0.04) & $\begin{array}{l}-0.0 .6 * * * * \\
(0.02)\end{array}$ & $\begin{array}{l}-0.5 .5 * 7 * \\
(0.05) \\
(0.7)\end{array}$ & $\begin{array}{l}-0.07 .7 * 4 \\
(0.04)\end{array}$ & $\begin{array}{l}-0.66 \\
(0.04)\end{array}$ & 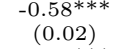 & $\begin{array}{c}-0.54 * * * \\
(0.04)\end{array}$ & $\begin{array}{l}-.056 * * \\
(0.03)\end{array}$ & $\begin{array}{l}-\begin{array}{c}-0.66 * * \\
(0.04)\end{array} \\
-\end{array}$ \\
\hline Medium banks & 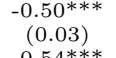 & 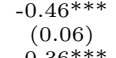 & 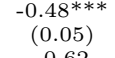 & $\begin{array}{l}-0.56 \\
(0.06) \\
0.067 x\end{array}$ & $\begin{array}{l}-0.05 \% * * \\
(0.04) \\
(0.04)\end{array}$ & 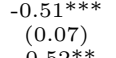 & 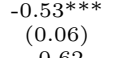 & $\begin{array}{l}-0.59 \\
(0.07)\end{array}$ & 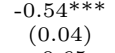 & $\begin{array}{c}-0.53^{* * *} \\
(0.08)\end{array}$ & $\begin{array}{c}-0.5 .5 * * \\
(0.06)\end{array}$ & $\begin{array}{l}-.05 *^{-5} \\
(0.07)\end{array}$ & $\left.\begin{array}{c}-0.50 * * * \\
(0.03)\end{array}\right)$ & $\begin{array}{c}-0.46 * * * \\
(0.06)\end{array}$ & $\begin{array}{l}-0.9 .9 * * * * \\
(0.05)\end{array}$ & $\begin{array}{l}-0.56 \\
(0.06)\end{array}$ \\
\hline Large banks & 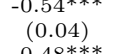 & 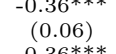 & $\begin{array}{l}-0.062 \\
0.06) \\
0.02 x\end{array}$ & 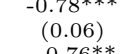 & 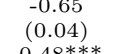 & 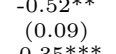 & 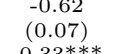 & 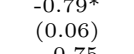 & $\begin{array}{c}-0.65 \\
(0.04) \\
(0.04)\end{array}$ & 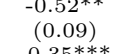 & 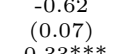 & $\begin{array}{l}-0.79 * \\
(0.06) \\
(0.06)\end{array}$ & 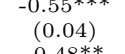 & 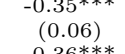 & 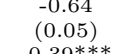 & 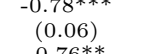 \\
\hline Major banks & $\begin{array}{l}-0.08 * * * \\
(0.04) \\
(0.4)\end{array}$ & $\begin{array}{l}-0.3 .6 * * * * \\
(0.06)\end{array}$ & $\begin{array}{l}-0.3 .3 * * *+ \\
(0.06)\end{array}$ & $\begin{array}{l}-0.77^{* * *} \\
(0.08)\end{array}$ & $\begin{array}{l}-0.08 * * * \\
(0.05)\end{array}$ & $\begin{array}{l}-0.05 .5 * * \\
(0.07)\end{array}$ & $\begin{array}{l}-0.033 * *+ \\
(0.07)\end{array}$ & $\begin{array}{l}-0.75 \\
(0.08)\end{array}$ & 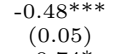 & 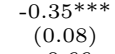 & $\begin{array}{l}-0.3 .3 * * *+ \\
(0.07)\end{array}$ & $\begin{array}{l}-0.7 \\
(0.0\end{array}$ & $\begin{array}{c}-0.48 * * \\
(0.04)\end{array}$ & $\begin{array}{l}-0.36 * * * \\
(0.06)\end{array}$ & 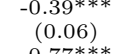 & 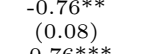 \\
\hline $\begin{array}{l}\text { Foreign banks } \\
\text { Dropped control }\end{array}$ & $\begin{array}{c}-0.077 \times 2 \times 2 \\
0.022\end{array}$ & $\begin{array}{l}-0.70 \\
0.040\end{array}$ & 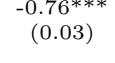 & & & 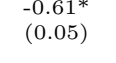 & $\begin{array}{c}-0.75 \\
{ }_{0.044}\end{array}$ & & $\begin{array}{c}-0.74^{*} \\
(0.03)\end{array}$ & $\begin{array}{l}-0.066 \\
(0.06)\end{array}$ & $\begin{array}{l}-0.8 \\
0.0\end{array}$ & & 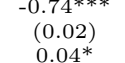 & 然. & * & \\
\hline Constant (Minor ref. group) & $-0.65^{* * *}$ & $-0.75^{* * *}$ & $-0.65^{* * *}$ & $-0.57 * *$ & $-0.699^{* * *}$ & $-0.70^{* * * *}$ & $-0.69 * * *$ & $* *$ & $-0.69^{* * *}$ & $70^{* * * *}$ & $-0.69^{* * *}$ & & $\begin{array}{c}-0.03 \sigma^{20 *} \\
-0\end{array}$ & $\begin{array}{l}(0.03) \\
-0.75 * *\end{array}$ & 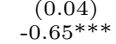 & \\
\hline Observations & 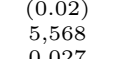 & 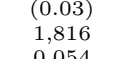 & 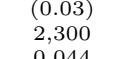 & $\begin{array}{l}(0.04) \\
1,452 \\
1,450\end{array}$ & $\begin{array}{l}\underbrace{}_{4,0.028} \\
4,030\end{array}$ & $\begin{array}{l}(0.04) \\
1,203 \\
1,201\end{array}$ & $\begin{array}{l}1,598 \\
1,598\end{array}$ & $\begin{array}{l}(0.04) \\
1,237 \\
1,27\end{array}$ & $\begin{array}{l}3,503 \\
\end{array}$ & $\begin{array}{l}(0.04) \\
1,020 \\
1,026\end{array}$ & 1,372 & 1,1111 & $\begin{array}{l}5,568 \\
, 588\end{array}$ & $\begin{array}{l}1,816 \\
1,16\end{array}$ & 2,300 & 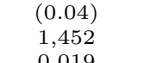 \\
\hline
\end{tabular}

